\title{
State Regulation of
}

\section{ResioentialFacilities for \\ Adults with Mental IIIness}
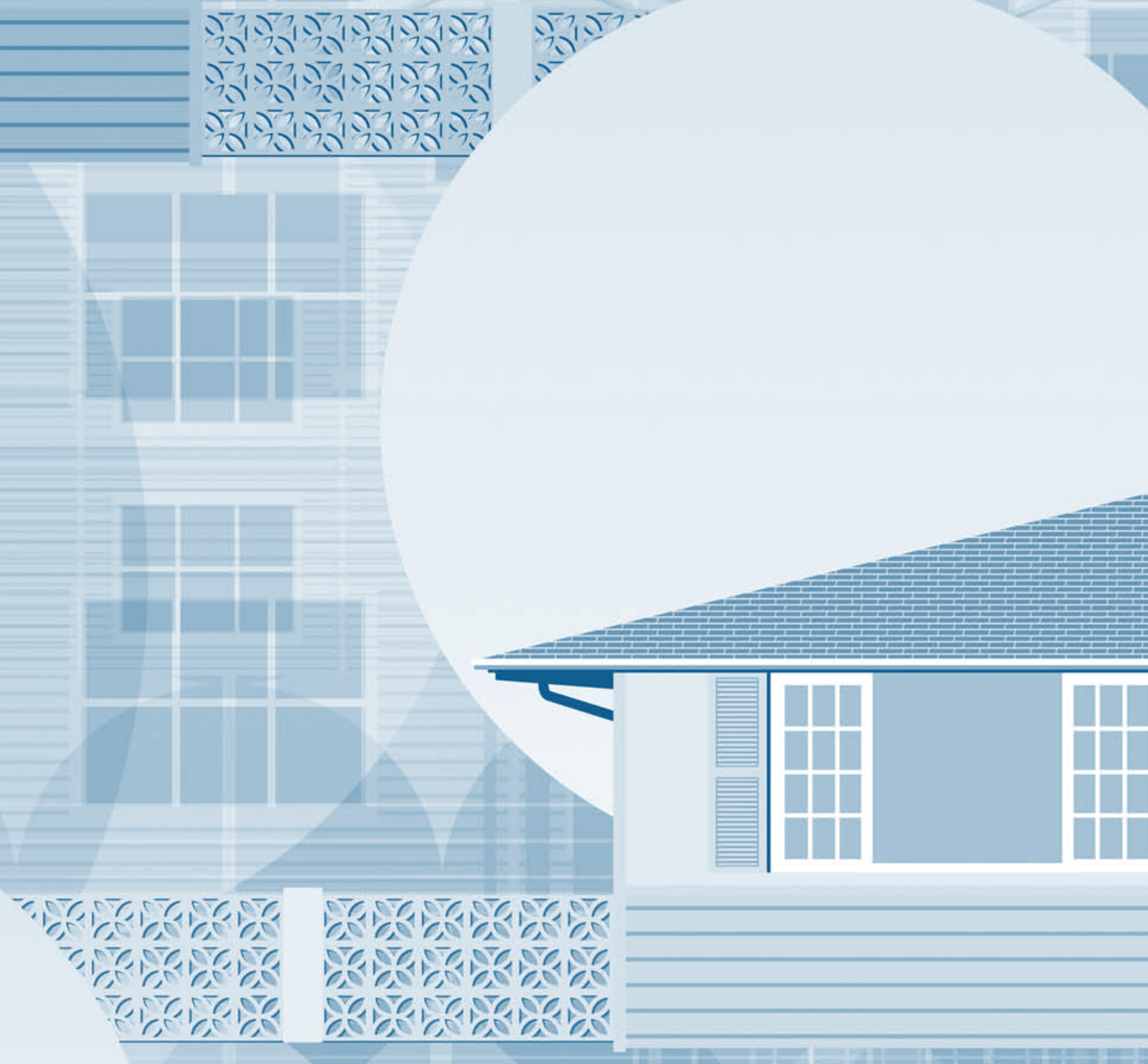

U.S. DEPARTMENT OF HEALTH AND HUMAN SERVICES Substance Abuse and Mental Health Services Administration Center for Mental Health Services www.samhsa.gov 



\section{State Regulation of \\ Residential Facilities for Adults with Mental IIIness}

Lori Achman

Ama Takyi 



\section{Acknowledgments}

This report was prepared by Mathematica Policy Research, Inc., for the Substance Abuse and Mental Health Services Administration (SAMHSA) of the U.S. Department of Health and Human Services (DHHS) under Contract No. 282-98-0021 (36). The authors of the report are Lori Achman, M.P.P., Henry Ireys, Ph.D., and Ama Takyi, M.A. Judith Teich, M.S.W., of the Center for Mental Health Services (CMHS), SAMHSA, served as government project officer, and Jeffrey A. Buck, Ph.D., Associate Director for Organization and Financing, CMHS, served as advisor.

\section{Disclaimer}

Material for this report was prepared by Mathematica Policy Research, Inc., for SAMHSA, DHHS, under Contract Number 282-98-0021, Task Order No. 36. The content of this publication does not necessarily reflect the views, opinions, or policies of CMHS, SAMHSA, or DHHS.

\section{Public Domain Notice}

All material appearing in this report is in the public domain and may be reproduced or copied without permission from SAMHSA or CMHS. Citation of the source is appreciated. However, this publication may not be reproduced or distributed for a fee without the specific, written authorization of the Office of Communications, SAMHSA, DHHS.

\section{Electronic Access and Copies of Publication}

This publication can be accessed electronically through the following Internet World Wide Web address: www.samhsa.hhs.gov. For additional free copies of this document, please call SAMHSA's National Mental Health Information Center at 1-800-789-2647 or 1-800-228-0427 (TTD).

\section{Recommended Citation}

Ireys H, Achman L, Takyi A. State Regulation of Residential Facilities for Adults with Mental Illness. DHHS Pub. No. (SMA) 06-4166. Rockville, MD: Center for Mental Health Services, Substance Abuse and Mental Health Services Administration, 2006.

\section{Originating Office}

Office of the Associate Director for Organization and Financing, Center for Mental Health Services, Substance Abuse and Mental Health Services Administration, One Choke Cherry Road, 6-1065, Rockville, MD 20857.

DHHS Publication No. (SMA) 06-4166

Printed 2006 



\section{Table of Contents}

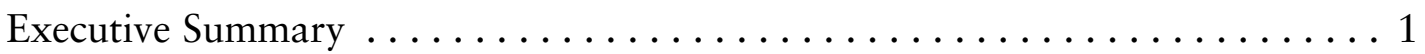

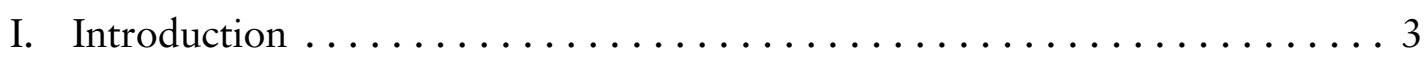

A. Mental Health Organizations Providing Residential Care . . . . . . . . . 4

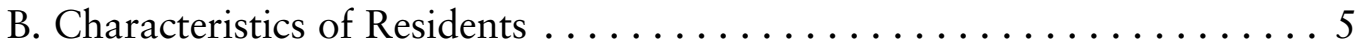

C. Summary $\ldots \ldots \ldots \ldots \ldots \ldots \ldots \ldots \ldots \ldots \ldots \ldots \ldots \ldots \ldots \ldots \ldots \ldots \ldots \ldots \ldots \ldots$

II. Methods and Data Issues $\ldots \ldots \ldots \ldots \ldots \ldots \ldots \ldots \ldots \ldots$

A. Criteria for Including Residential Facilities in the Present Study . . . . . . 7

B. Questionnaire Development . . . . . . . . . . . . . . . 8

C. Fielding the Survey $\ldots \ldots \ldots \ldots \ldots \ldots \ldots \ldots \ldots$

D. Assessing Data Quality . . . . . . . . . . . . . . . . . 10

III. Number and Characteristics of Residential Facilities for Adults with Mental Illness . . . . . . . . . . . . . . . . . . 13

A. Number of Facilities and Associated Beds . . . . . . . . . . . . 13

B. Average Number of Residents. . . . . . . . . . . . . . . . . . . 17

C. Average Length of Stay. . . . . . . . . . . . . . . . . . . . . 17

D. Organizations that Operate Residential Facilities . . . . . . . . . 18

E. Secure Units . . . . . . . . . . . . . . . . . . . . 18

IV. State Oversight: Requirements, Licensing, Regulations. . . . . . . . . . . . . 19

A. Basic Requirements for Facilities . . . . . . . . . . . . . . . . . . . 19

1. Staff-to-Resident Ratio Requirements . . . . . . . . . . 19

2. Minimum Education of Facility Directors . . . . . . . . 20

3. Critical Incident Reporting Requirements . . . . . . . . . 20

B. Licensing Agencies . . . . . . . . . . . . . . . . . . . 21

C. Regulatory Practices......................... 22

D. Agencies Responsible for Reviewing Complaints......... . . . . . 23

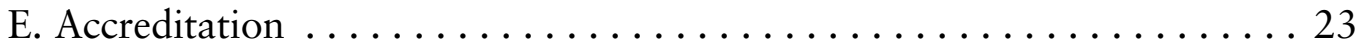

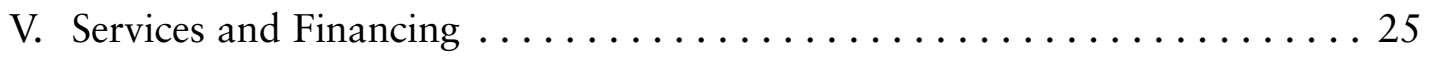

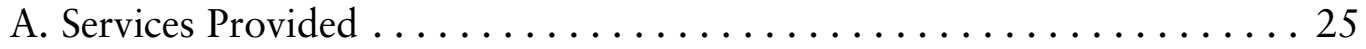

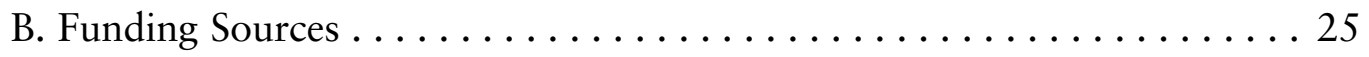

VI. Conclusions. . . . . . . . . . . . . . . . . . . . . . . . . . . 29

References............................ 31

Appendix A: Expert Advisory Panel .................... 33

Appendix B: Survey Questionnaire................... 35 


\section{List of Tables}

I.1. Average Daily Census of Adults 21 Years and Older and Number of Beds in 24-Hour Residential Care Organizations Funded and Operated by State Mental Health Agencies, 2002 . . . . . . . . . . . 4

II.1. Criteria for Residential Facilities to Be Included in the Study . . . . . . 8

II.2. Percentage of Respondents Using Estimates or Record Reviews for Selected Survey Items . . . . . . . . . . . . . . . . . . 11

III.1. Types of Residential Facilities for Adults with Mental Illness, Average Number of Residents, and Total Beds, by State, September 30, 2003.......................... 14-15

III.2. Number of Beds in Residential Facilities for Selected States for Selected Months as Reported in Two Data Sources ............. 16

III.3. Average Number of Residents per Residential Facility for Adults with Mental Illness, 2003 . . . . . . . . . . . . . . . . . . . . . 17

III.4. Average Length of Stay in Residential Facilities for Adults with Mental Illness, by Number of Facilities, 2003 . . . . . . . . . . . . . 17

III.5. Ownership of Residential Facilities for Adults with Mental Illness, by Number of Facilities, 2003 . . . . . . . . . . . . . . . . 18

IV.1. Daytime Staff-to-Resident Ratio Requirements in Residential Facilities for Adults with Mental Illness, 2003 . . . . . . . . . . . 20

IV.2. State Regulations Requiring Minimum Education for Residential

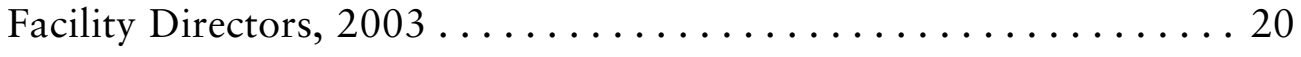

IV.3. Requirements for Reporting Critical Incidents to the State in Residential Facilities for Adults with Mental Illness, 2003 . . . . . . . 21

IV.4. Number of Agencies Involved in Licensing or Certifying Residential Facilities for Adults with Mental Illness, 2003 . . . . . . . . . . 21

IV.5. State Agencies Involved in Licensure or Certification of Residential Facilities for Adults with Mental Illness, 2003 . . . . . . . . . . 22

IV.6. Procedures Required by States for Initial Licensure or Certification and Renewal of Licensure or Certification for Residential Facilities for Adults with Mental Illness, 2003.................... 22 
IV.7. Number of Agencies Responsible for Reviewing Complaints Against Residential Facilities for Adults with Mental Illness . . . . . . . . . 23

IV.8. State Agencies that Review Complaints Against Residential Facilities for Adults with Mental Illness, 2003. . . . . . . . . . . . . . . . . . 24

V.1. Services that Residential Facilities Must Provide per State Requirements, Either by Staff or Through Contractual

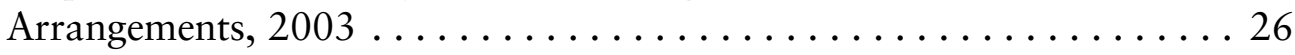

V.2. Funding Sources for Residential Facilities for Adults with Mental

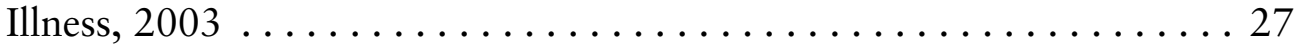





\section{Executive Summary}

T

here is little national information on the policies and procedures used by States to regulate residential treatment facilities for adults with mental illness. As a result, policymakers and program administrators face major difficulties in determining both the effectiveness of current policies and the potential need for new policies that are responsive to emerging trends in mental health care. Based on a survey of State officials, this report provides the most accurate national data available concerning methods that States use to license, regulate, and monitor residential facilities for adults with mental illness. The information in this report can help Federal and State policymakers improve procedures for monitoring quality of care provided in these facilities.

The specific purpose of this study was to conduct a national survey of State officials to identify methods that States use to monitor residential facilities for adults with mental illness. Officials in departments of mental health, social services, and health and human services responded to structured questions on facility characteristics and programs, licensing and oversight procedures, and sources of financing. The survey was fielded between November 2003 and March 2004. This report presents the results of the survey.

\section{Residential Facilities in the Study}

To be included in the study, residential facilities for adults with mental illness had to be licensed or certified by the State as providing some therapeutic services in addition to room and board. States vary widely in the types of residential facilities that they license or certify, the names of these facility types, and the number of associated facilities.

Because this study focuses on State regulations, facility type is the primary unit of analysis, but the study also covers the num- ber of facilities in each type and the number of licensed beds. Many States license multiple types of residential facilities for adults with mental illness. For example, in one State, the two types of residential facilities meeting study criteria are referred to as "long-term structured residential facilities" and "community residential rehabilitation group homes." The first type includes 25 facilities with 359 associated beds; the second type includes 545 facilities and 2,726 associated beds.

In 2003, the number of facilities associated with each facility type included in the study varied by State from 1 to more than 1,300 . The average number of residents per facility ranged from 3 to 99 . About 39 percent of the facilities housed between 3 and 8 residents, and 79 percent of facilities averaged fewer than 17 residents each. About 43 percent of all facilities are owned wholly or predominantly by not-for-profit organizations, and about 6 percent by forprofit organizations.

The study data derive from responses by officials in 34 States and the District of 
Columbia who provided information on 63 types of residential facilities. These 63 types account for 7,327 facilities that, in total, had 103,393 beds as of September 30, 2003. These numbers exceed counts based on the Survey of Mental Health Organizations (cf. Manderscheid et al., 2004) because the present study covered a wider range of residential settings. Overall, the study adds substantially to existing information on the number and characteristics of mental health organizations providing residential care to adults with mental illness.

\section{Major Findings on States' Monitoring Methods}

The analysis of survey data led to two major findings. First, States use a variety of methods for monitoring residential facilities for adults with mental illness, and they vary in the extent to which they use one method or another. Typical methods include onsite inspections, documentation of staff qualifications and training, record reviews, resident interviews, critical-incident reports, and standards for resident-to-staff ratios and educational levels of facility directors. All States use at least several of these methods, but few States use all of them.

Second, the regulatory and monitoring environment for residential facilities that serve adults with mental illness is complex because in most States, several agencies, each with a different mission and function, are involved in facility licensing, funding, and oversight. These agencies include State mental health authorities, departments of health, and departments of social services. For 61 percent of the types of residential facilities covered by the survey, two or more State agencies are involved in reviewing complaints, and for 37 percent of all facility types, licensing or certification is required from more than one agency. Furthermore, in some States, agencies that provide major financial support play a minor regulatory role.

Other findings include the following:

- Slightly less than 60 percent of facility types, accounting for 25 percent of facilities, were subject to State requirements limiting the maximum number of residents allowed per staff person in 2003.

- To obtain initial licenses or license renewals, virtually all facilities were required to undergo a site inspection, and between 55 and 90 percent were required to (1) provide documentation of staff qualifications and (2) permit State review of clinical records.

- States conducted unannounced visits for monitoring purposes to at least some facilities within 65 percent of all facility types; States conducted announced visits to at least some facilities within 70 percent of all facility types.

- More than 85 percent of facilities were required to report adverse events or critical incidents to the State, but the specific types of adverse events or incidents that must be reported vary somewhat across facilities.

- State and local mental health agencies were the most common funding source for residential facilities for adults with mental illness; 79 percent of facility types, accounting for 84 percent of associated facilities, receive at least some funding from the State or local mental health agency.

- Residents use Supplemental Security Income payments to pay for services in 70 percent of facility types, accounting for 84 percent of associated facilities; residents also use Social Security Disability Insurance payments in 59 percent of facility types, accounting for 47 percent of associated facilities. 


\section{Introduction}

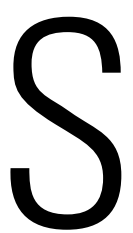

ince deinstitutionalization of individuals with mental illness

began in the 1960s, residential facilities for adults with mental

illness have changed substantially and are now an important component of State mental health service systems. For example, over the past two decades, residential programs have moved from simply providing custodial care to an emphasis on independent living and self-sufficiency, and larger congregate facilities have been replaced by smaller residential settings (O’Hara \& Day, 2001; Ridgway \& Zipple, 1990). Despite the importance of residential facilities for adults with mental illness, comprehensive information on their characteristics and number of residents is sparse (Salzer, Blank, Rothbard, \& Hadley, 2001, Fleishman, 2004). Moreover, States have long held the primary responsibility for regulating these facilities, but there has never been a systematic survey of the States' regulatory methods.

This report presents the results of a survey of State agencies about current State licensing and regulatory procedures for residential facilities for adults with mental illness. (A companion report, State Regulation of Residential Facilities for Children with Mental Illness, provides information about residential treatment facilities for children.)

This chapter summarizes information from previous studies on the number of these facilities and the characteristics of their residents. Specifically, it reviews data from four sources:

- the Survey of Mental Health Organizations (SMHO) for 2002,

- reports from the Research Institute of the National Association of State Mental Health Program Directors (NASMHPD) based on 2002 data from the States,
- the National Survey of Community Residential Programs for Persons with Prolonged Mental Illness (NSCRP) fielded in 1986-1987, and

- analyses of data from the 1997 Client/ Patient Sample Survey (CPSS).

Chapter II provides an overview of the methods used to obtain data from the States and includes the criteria used to identify residential facilities for the survey. Chapters III to $\mathrm{V}$ present the findings of the survey in a series of tables, with important findings discussed in the text: Chapter III focuses on the numbers and characteristics of residential facilities, Chapter IV on State regulatory methods, and Chapter $\mathrm{V}$ on services and financing. Chapter VI presents conclusions based on the findings. The appendix includes the survey used to collect data from the States. 


\section{A. Mental Health Organizations Providing Residential Care}

The SMHO, conducted every 2 years by the Center for Mental Health Services at the Substance Abuse and Mental Health Services Administration (SAMHSA), is a count of specialty mental health organizations and psychiatric services of non-Federal general hospitals and a survey of a sample of these organizations that collects information on services, beds, staffing, expenditures, and sources of revenue. Analyses of data from the SMHO conducted in 2002 indicate that 781 mental health organizations (excluding all types of psychiatric hospital or inpatient settings) had 44,886 beds for residential care for adults (Manderscheid et al., 2004). The SMHO focuses specifically on organizations that operate under the authority of mental health agencies and have the provision of clinical mental health services as their primary mission (J. Maedke, Social and Scientific Systems, Inc., personal communication, April, 2005). It does not include many other residential facilities that are not under the authority of State mental health agencies or that serve as homes to adults with mental illness who may need only supportive services, such as case management, training in activities of daily life, or medication management.

In addition to the SMHO, some information on the number of individuals in residential treatment beds operated and funded by State mental health authorities is available for selected States through the NASMHPD Research Institute's State Profile Report for 2002. As Table I.1 shows, States that submitted data vary widely in the daily average of adults who were in residential settings owned or operated by State mental health agencies. The NASMHPD study defines residential beds as providing (1) overnight mental health

\begin{tabular}{|c|c|c|}
\hline \multicolumn{3}{|c|}{$\begin{array}{l}\text { Table I.1. Average Daily Census } \\
\text { of Adults } 21 \text { Years and Older } \\
\text { and Number of Beds in 24-Hour } \\
\text { Residential Care Organizations } \\
\text { Funded and Operated by State } \\
\text { Mental Health Agencies, } 2002\end{array}$} \\
\hline State & $\begin{array}{l}\text { Average Daily } \\
\text { Census of Clients }\end{array}$ & $\begin{array}{l}\text { Number } \\
\text { of Beds }\end{array}$ \\
\hline Alabama & 1,877 & 2,086 \\
\hline California & 4,268 & - \\
\hline Colorado & 642 & - \\
\hline Connecticut & 949 & 1,176 \\
\hline Delaware & - & 180 \\
\hline Florida & 1,960 & - \\
\hline Hawaii & 132 & 240 \\
\hline Massachusetts $^{a}$ & 6,990 & - \\
\hline Michigan & 2,880 & - \\
\hline Minnesota & 606 & - \\
\hline Missouri & 65 & 81 \\
\hline$N^{2} a_{a d a}{ }^{b}$ & 708 & - \\
\hline New Hampshire & 29 & - \\
\hline New Jersey & 3,284 & - \\
\hline New Mexico & 39 & 44 \\
\hline New York & 6,395 & 6,914 \\
\hline Oklahoma & 101 & 199 \\
\hline Oregon & 934 & 1,186 \\
\hline Rhode Island $\mathrm{d}^{\mathrm{b}}$ & 304 & 314 \\
\hline South Carolina & 23 & 30 \\
\hline Texas & 272 & - \\
\hline Utah & 417 & 459 \\
\hline Vermont & 336 & - \\
\hline Wyoming & 7 & - \\
\hline Total & - & 12,909 \\
\hline \multicolumn{3}{|c|}{ Source: NASMHPD, 2005} \\
\hline \multicolumn{3}{|c|}{$\begin{array}{l}\text { Notes: Other States did not provide any information for these items or } \\
\text { had no residential care organizations funded and operated by the } \\
\text { State's mental heatlth organization. Dashes (- Indicate State did } \\
\text { not respond to the specific item. Average daily census is for fiscal } \\
\text { year 2002. Number of beds is as of the last day of fiscal year } 2002 \text {. } \\
\text { Twenty-four-hour residential care is defined as overnight mental } \\
\text { health care in conjunction with (1) psychiatric treatment services } \\
\text { in a setting other than a hospital or (2) supervised living and other } \\
\text { supportive services in a setting other than a hospital. Examples } \\
\text { include halfway houses, community residences, and group homes. } \\
\text { The average daily census of clients in Connecticut is based on the } \\
\text { State's } 2004 \text { report. } \\
\text { a Adults } 20 \text { years and older. } \\
\text { b Adults } 18 \text { years and older. }\end{array}$} \\
\hline
\end{tabular}

care in conjunction with psychiatric treatment services in a setting other than a hospital or (2) overnight mental health care in conjunction with supervised living and other supportive services in a setting other than a hospital (NASMHPD, 2005). 
Finally, although it is quite dated, the NSCRP provides a comprehensive view of the residential treatment system in 1986-87. The purpose of the survey was to develop a national database to describe how mental health systems across the country had responded to the housing needs of adults with mental illness (Randolph, Ridgway, Sanford, Simoneau, \& Carling, 1988). Information gathered in the survey focused on what agencies developed residential programs, the types of programs that were implemented, the services provided, and staff and client characteristics. The survey identified more than 2,500 agencies that provided community residential programs to adults with psychiatric disabilities and found that about 60,000 adults were residing in community residential programs in 1986-87.

The following types of residential programs were included in the survey: shelter programs, crisis programs, foster care programs, supervised apartments, group homes, board and care facilities, halfway houses, intermediate care facilities, nursing homes, and supportive housing arrangements. According to the NSCRP, in 1986-87, most of the agencies providing residential services were private, nonprofit organizations that relied heavily on state funds to start and operate their programs (Randolph et al., 1988). The most frequent types of programs offered by the agencies were group homes and supervised apartment programs.

\section{B. Characteristics of Residents}

The 1997 CPSS provides information on characteristics of persons served by residential care programs. This survey included residential care programs of State and county mental hospitals, private psychiatric hospi- tals, non-Federal general hospitals, Veterans Administration medical centers, and multiservice mental health organizations that were included in the 1994 Inventory of Mental Health Organizations and General Hospital Mental Health Services (Milazzo-Sayre et al., 2001). According to the CPSS, 55,274 adults were under the care of residential programs on May 1, 1997, and there were 128,042 admissions during 1997 (Milazzo-Sayre et al., 2001). Males represented about 60 percent of the client population. Overall, persons diagnosed with schizophrenia were the most likely to be under the care of residential programs, representing 50 percent of clients served in these facilities.

\section{Summary}

Existing information provides a foundation for understanding the nature and scope of residential care for adults with mental illness, but major gaps in data on these residential settings remain. In particular, certain types of residential settings were not included in existing surveys or profiles, such as settings that provide a minimum level of therapeutic services beyond room and board and that were not operated under the auspices of State mental health agencies. Furthermore, existing studies or surveys do not address the methods States use to regulate or monitor these facilities.

The present study builds on the existing foundation of data by gathering information on State methods of regulating residential facilities for adults with mental illness. The types of facilities that States regulate include facilities that do not meet criteria for inclusion in the SMHO, and therefore this study reports on a larger number of facilities than have been included in studies based on SMHO data. 



\section{Methods and Data Issues}

$\mathrm{n}$ the absence of national data on policies and procedures that States used to regulate and monitor residential facilities for adults with mental illness, this study required a systematic approach to gathering relevant information from officials in State departments of mental health, social services, and health and human services, and other agencies involved in monitoring these facilities. The study was organized around the following steps to accomplish its goals:

- Determining the criteria for including residential facilities

- Developing the survey questionnaire

- Fielding the survey

- Assessing the quality of the data

\section{A. Criteria for Including Residential Facilities in the Present Study}

The present study uses a structured survey to gather information about State-regulated residential facilities specifically designed to serve adults with mental illness (as opposed to settings that serve individuals with physical disabilities and the elderly) and that provide some therapeutic service beyond room and board. Adults with mental illness live in a wide variety of community settings, including subsidized apartments, short-stay residences, and their own homes, but this study was not designed to gather information on these settings. In addition, the survey was not intended to cover psychiatric inpatient facilities, nursing homes, residential substance abuse treatment programs (unless the program was specifically for individuals dually diagnosed with a mental disorder and a substance abuse disorder), or individual care arrangements.
One of the obstacles to collecting national information on residential facilities for adults with mental illness is the absence of a standard nomenclature. Because responsibility for monitoring residential settings for adults with mental illness lies with State governments, each State has evolved its own terms to describe the types of facilities available in the State. As Fleishman (2004) notes, residential care facilities "are also known as board-and-care homes, adult residential facilities, adult foster homes, adult homes, community care homes, supervisory care homes, sheltered care facilities, continuing care facilities, transitional living facilities, group homes, domiciliary care homes, personal care homes, family care homes, and rest homes, among others."

In this report, "residential facility" refers to any entity that meets the criteria listed in Table II.1. These criteria were developed with guidance from the project's advisory committee following a review of descrip- 


\section{Table II.1. Criteria for \\ Residential Facilities to Be Included in the Study}

To be included in this study, facilities had to:

- Specialize in the treatment of adults with mental illness including individuals who are dually diagnosed (mental illness and substance abuse or mental illness and developmental disability) as long as mental illness was the primary problem

- Be an establishment that furnished (in single or several facilities) food, shelter, and some treatment or services to three or more adults unrelated to the proprietor

- Provide staffing 24 hours per day, 7 days per week

- Operate under some State authority, such as a State office granting pertinent licenses or a State mental health authority

- Include at least 50 percent of residents whose need for placement was based on mental illness

- Include individuals with average stays of 30 days or longer

- Provide at least some on-site therapeutic services beyond room and board (e.g., training in activities of daily living, vocational training, medication management) either by staff or under contract

tions of State mental health systems. Some States support other residential arrangements for adults with mental illness that would not meet these criteria. For instance, supported housing arrangements in which individuals live alone in scattered apartments across a city would not meet our study criteria but nonetheless remain an important, emerging type of housing assistance for adults with mental illness. Although this report does not include all possible types of residential settings for adults with mental illness, it provides the most comprehensive effort to date to examine the regulatory methods that States use for residential treatment facilities available for adults with mental illness.

\section{B. Questionnaire Development}

The goal of the questionnaire was to gather descriptive information on specific aspects of residential facilities for adults with mental illness for comparison across States. As a first step, information was obtained from a review of Web sites of 10 States of different sizes from different regions of the country. Specifically, information was gathered on the rules and regulations promulgated by these States for residential facilities for adults with mental illness.

This task made it clear that States relied on different regulations and monitoring practices for different types of licensed facilities. Accordingly, a survey method was developed that allowed State officials to respond separately for each type of facility.

The review of information available on the States' Web sites also was used to develop specific items in the following five topic areas:

1. Facility characteristics (including number of residents, number of beds, average length of stay, and staffing ratios)

2. Licensing, certification, and accreditation (including the agencies responsible for licensing/certifying facilities and the steps associated with the provision and renewal of licenses and certifications)

3. Facility programs and treatment services (including requirements for individualized treatment plans and services that must be available to residents)

4. Methods used for monitoring and oversight (including the agencies responsible for conducting monitoring visits, handling grievances and complaints, and criticalincident reporting)

5. Financing (including funding sources and per diem rates) 
With these five topics in mind, an initial draft of the questionnaire was developed and sent to a group of mental health experts for comment. On the basis of the experts' input, the questionnaire was revised and pilot-tested in three States. The questionnaire underwent further modification after the pilot test to make the questions more concise and less burdensome to respondents. The appendix includes the final version of the survey.

\section{Fielding the Survey}

The survey implementation phase of the project involved the following tasks:

- Web searches were conducted for all States to identify (1) a preliminary list of program types that met the study's criteria and (2) State officials (e.g., the director of the mental health agency) who potentially could serve as primary contacts.

- These individuals, or the persons who were in the same position if the initial contacts had left, were contacted by mail and telephone to verify the list of program types, amend the types as needed, and ask the person to serve as the primary contact. (An average of four to five telephone calls or emails per State were made before establishing a primary contact and, after a contact person was identified, an average of three to four telephone or email contacts were needed to verify the list of program types. Overall, an average 4 hours per State were needed to conduct initial Web searches, identify the contact person, and compile a final list of program types.)

- Each person who agreed to be a primary contact received a formal letter from the project officer at SAMHSA detailing the purpose of the study and thanking him or her for supporting the project.
- The contact person was sent one or more questionnaires, depending on the number of program types in the State. (The specific name of the program type was included on a cover page and strategically embedded in the questionnaire to ensure that respondents knew to which program type the questions applied. A comprehensive instruction guide assisted respondents in completing the survey.)

Depending on the preference of the contact person, surveys were mailed, faxed, or emailed. Respondents could return the completed questionnaire by mail, fax, or email or complete the questionnaire in a telephone conversation with an interviewer. Surveys sent by email were based on an Excel spreadsheet so that respondents could reply to the questions on screen, save the survey, and return it in the spreadsheet format. In all cases, the material included a second cover letter from the project officer at SAMHSA, the list of criteria that defined the types of programs of interest to the study, and specific instructions regarding the survey.

The first questionnaire was mailed in October 2003, and the last completed one was received in March 2004. Most of the questionnaires were sent out and returned by email; most were completed and returned within 2 to 3 weeks, although several months were needed to obtain a completed questionnaire from some States. Although a primary contact was available in each State, several individuals typically were involved in responding to the questionnaire because, in most States, no one person was familiar with all topics covered in the questionnaire. For example, one individual was familiar with service requirements while another was familiar with financing. After a survey was 
received, it was reviewed, and followup telephone calls or emails were made to clarify ambiguous responses or fill in missing data, if possible. When all questions were resolved, a questionnaire was considered complete, and a thank-you card was mailed to the primary contact.

A total of 86 surveys were mailed to 44 of the 51 States (including the District of Columbia); 35 States returned at least one usable questionnaire. Of the remaining 16 States:

- Six States did not respond to our request to participate in the survey (repeated calls and emails to the contact person went unanswered, or no primary contact could be located).

- Two States opted to provide a brief explanation of the housing options for adults with mental illness, rather than completing a questionnaire.

- Eight States (Alaska, Arizona, Arkansas, Kentucky, Michigan, New Hampshire, New Mexico, and Ohio) had programs that did not fit our criteria (e.g., the State used only foster homes or assisted living apartments; the programs provided only room and board; less than 50 percent of residents had mental illness; or facilities included fewer than three persons).

Overall, of the 50 States and the District of Columbia, usable information was provided by 43 States ( 84 percent): the 35 States completing at least one questionnaire and the 8 States indicating that they did not regulate facilities that met the study criteria. Information from the questionnaires was entered into a standard SAS database. Several rounds of detailed data verification with State officials occurred between
July and October 2004. The final database included information on 63 types of residential facilities for adults with mental illness in 35 States (including the District of Columbia).

\section{Assessing Data Quality}

Survey respondents had several opportunities to verify the submitted data and to complete as much of the questionnaire as possible. As questionnaires were received, research staff performed quality checks to see if any responses did not seem plausible. If staff members had questions about survey responses, they called the respondents to clear up any confusion. A final data check was conducted by downloading information from completed questionnaires into 2-page templates, which were sent back to the appropriate contact person for final verification and with a request for any missing information on facility characteristics. Several States suggested minor changes.

Although the data are the best available to date, States frequently did not have all the statistical data needed to respond to the survey questions. For instance, one State could not respond to the survey because the requested information spanned a number of agencies and the State was unable to coordinate a response. In other cases, States do not collect the necessary data, such as average length of stay, occupancy rates, and the average number of residents per facility. In some States, officials indicated that they could not provide the data on facility characteristics owing to the impracticality (i.e., too timeconsuming) or impossibility (i.e., the relevant data were not available) of collecting the information.

As a check of data quality, researchers asked respondents to indicate whether their 
responses to seven of the survey questions were based on experience-based estimates or reviews of specific records or statistical data. Depending on the item, between 11 and 75 percent of respondents indicated that they based their response on reviews of specific records or statistical data (see Table II.2). Hence, some numbers in this report-such as the number of facilities nationwide, the average number of residents, or the average length of stay-should be viewed as estimates rather than as precise figures.
Overall, the quality of the information presented in this report depends on the extent and accuracy of the information available to respondents. Because of extensive efforts to check questionable data through telephone calls and emails to State officials and State approval of the final data used for the analyses, the report reflects the most accurate national data available on characteristics of the facilities that meet the study's criteria and the methods that States use to monitor these residential facilities.

\begin{tabular}{|c|c|c|c|c|}
\hline Survey Item & $\begin{array}{c}\text { Percentage } \\
\text { Unable to } \\
\text { Answer } \\
\text { Item }\end{array}$ & $\begin{array}{c}\text { Percentage } \\
\text { Using } \\
\text { Estimate } \\
\end{array}$ & $\begin{array}{c}\text { Percentage } \\
\text { Using Record } \\
\text { Reviews } \\
\end{array}$ & $\begin{array}{c}\text { Percentage } \\
\text { Answering } \\
\text { but Not Indicating } \\
\text { Whether Response } \\
\text { Was Based } \\
\text { on Record } \\
\text { Review or Estimate } \\
\end{array}$ \\
\hline Number of facilities & 4.8 & 17.5 & 74.6 & 3.2 \\
\hline Average number of residents & 6.3 & 50.8 & 27.0 & 15.9 \\
\hline Average length of stay & 39.7 & 46.0 & 11.1 & 3.2 \\
\hline $\begin{array}{l}\text { Percentage of facilities with secure units, } \\
\text { if the facility is allowed secure units }\end{array}$ & 0.0 & 25.0 & 75.0 & 0.0 \\
\hline $\begin{array}{l}\text { Percentage of facilities with an unannounced } \\
\text { visit, if the State conducted unannounced visits }\end{array}$ & 4.8 & 57.1 & 38.1 & 0.0 \\
\hline $\begin{array}{l}\text { Percentage of facilities with an announced } \\
\text { visit, if the State conducted announced visits }\end{array}$ & 9.3 & 46.5 & 44.2 & 0.0 \\
\hline $\begin{array}{l}\text { Medicaid per diem, if State has a Medicaid } \\
\text { per diem }\end{array}$ & 0.0 & 50.0 & 50.0 & 0.0 \\
\hline
\end{tabular}





\section{Number and}

Characteristics of

Residential Facilities for

Adults with Mental IIIness

T

he survey yielded information on 63 types of residential facilities in 34 States and the District of Columbia. There was considerable variation in the number of facilities associated with each facility type, the average number of residents in a single facility within each type, and the total number of beds in operation in all facilities within a facility type (see Table III.1). For example, Connecticut has developed regulations for two types of residential facilities that meet study criteria: "mental health residential living centers" and "mental health community residences." The first type includes 20 facilities, with an average number of 10 residents per facility and a total number of 203 beds; the second type includes 6 facilities with an average number of 8 residents and a total number of 48 beds. Oklahoma also has developed regulations for two types of residential facilities ("residential care homes for adults" and "enhanced residential care homes for adults"); the first includes more than 100 facilities that had on average 32 residents, and the second includes 3 facilities with an average number of 26 residents.

\section{A. Number of Facilities and Associated Beds}

As Table III.1 indicates, the number of facilities per facility type ranged from 1 facility in Delaware (in a type of facility referred to as "dual-diagnosed residential") to 1,373 facilities in Wisconsin (in a type of facility referred to as "community-based residential facilities”). In total, the responding States reported 7,327 residential facilities, accounting for 103,393 beds.
As noted previously, analyses based on data from the SMHO indicate that 781 nonhospital mental health organizations provided 24-hour care in 2002 and that these organizations had 44,886 beds in operation (Manderscheid et al., 2004). The numbers from the present study are substantially higher because it includes a larger range of facilities than did the SMHO. Specifically, the SMHO was developed to provide counts of mental health organizations, including 


\begin{tabular}{|c|c|c|c|c|}
\hline State & Name of Facility Type & $\begin{array}{c}\text { Number } \\
\text { of } \\
\text { Facilities }\end{array}$ & $\begin{array}{l}\text { Average } \\
\text { Number of } \\
\text { Residents } \\
\text { per Facility }\end{array}$ & $\begin{array}{c}\text { Total } \\
\text { Number } \\
\text { of Beds }\end{array}$ \\
\hline \multirow[t]{4}{*}{ California } & Long-Term Residential Treatment Facilities & $\mathrm{N} / \mathrm{A}$ & $\mathrm{N} / \mathrm{A}$ & 83 \\
\hline & Transitional Residential Treatment Facilities & $\mathrm{N} / \mathrm{A}$ & 6 & 627 \\
\hline & Skilled-Nursing Facilities with Special Treatment Programs & 31 & 99 & 3,081 \\
\hline & Mental Health Rehabilitation Center & 21 & 73 & 1,550 \\
\hline \multirow[t]{3}{*}{ Connecticut } & Mental Health Residential Living Centers & 20 & 10 & 203 \\
\hline & Mental Health Community Residences & 6 & 8 & 48 \\
\hline & Residential Care Homes & 106 & 15 & 2,874 \\
\hline \multirow[t]{2}{*}{ Delaware } & Licensed Mental Health Group Homes & 14 & 8 & 122 \\
\hline & Dual-Diagnosed Residential & 1 & 13 & 16 \\
\hline $\begin{array}{l}\text { District of } \\
\text { Columbia }\end{array}$ & Mental Health Community Residential Facilities & 148 & 8 & 1,033 \\
\hline \multirow[t]{4}{*}{ Florida } & Level I-A Residential Treatment Facilities & 8 & 13 & 106 \\
\hline & Level I-B Residential Treatment Facilities & 4 & 30 & 118 \\
\hline & Level II Residential Treatment Facilities & 63 & 10 & 634 \\
\hline & Level III Residential Treatment Facilities & 28 & 23 & 653 \\
\hline Hawaii & 24-Hour Group Homes & 11 & 8 & 272 \\
\hline Idaho & Residential and Assisted Living Facilities & 261 & 18 & 6,085 \\
\hline \multirow[t]{2}{*}{ Illinois } & Community Integrated Living Arrangement & 119 & 5 & 583 \\
\hline & Supervised Residential & 105 & 10 & 910 \\
\hline \multirow[t]{5}{*}{ Indiana } & Semi-Independent Living Program & $\mathrm{N} / \mathrm{A}$ & 6 & 1,008 \\
\hline & Alternative Families for Adults & 36 & 4 & 144 \\
\hline & Transitional Residential Facilities & 32 & 13 & 429 \\
\hline & Supervised Group Living Facility & 75 & 14 & 1,025 \\
\hline & Subacute Facilities & 13 & 20 & 258 \\
\hline Kansas & Residential Care Facilities_-Adults & 34 & 12 & 428 \\
\hline Louisiana & Supportive Housing Apartments_-Adults & 15 & 20 & 316 \\
\hline Maine & Residential Program for Adults & 32 & 6 & 176 \\
\hline Maryland & Group Homes for Adults with Mental Illness & 99 & 6 & 645 \\
\hline \multirow[t]{2}{*}{ Massachusetts } & 24-Hour Group Homes-Adults & 360 & 10 & 2,730 \\
\hline & Supported Housing—Adults & 335 & 12 & 316 \\
\hline Minnesota & Rule 36 Residential Facilities for Adults with Mental Illness & 71 & 33 & 2,360 \\
\hline \multirow[t]{2}{*}{ Mississippi } & Group Homes & 44 & 16 & 514 \\
\hline & Halfway Houses & 3 & 9 & 35 \\
\hline
\end{tabular}




\begin{tabular}{|c|c|c|c|c|}
\hline \multicolumn{5}{|c|}{ Table III.1. (continued) } \\
\hline & Name of Facility Type & $\begin{array}{c}\text { Number } \\
\text { of } \\
\text { Facilities }\end{array}$ & $\begin{array}{c}\text { Average } \\
\text { Number of } \\
\text { Residents } \\
\text { per Facility }\end{array}$ & $\begin{array}{c}\text { Total } \\
\text { Number } \\
\text { of Beds }\end{array}$ \\
\hline \multirow{5}{*}{$\begin{array}{l}\text { State } \\
\text { Missouri }\end{array}$} & Residential Care Facility (RCF II) & 70 & N/A & N/A \\
\hline & Residential Care Facility (RCF I) & 70 & $\mathrm{~N} / \mathrm{A}$ & N/A \\
\hline & Mental Health RCF II & 7 & $\mathrm{~N} / \mathrm{A}$ & N/A \\
\hline & Psychiatric Group Home I & 2 & 8 & 8 \\
\hline & Psychiatric Group Home II & 2 & 8 & 16 \\
\hline Montana & Group Homes_-Adults & 10 & 8 & 76 \\
\hline Nebraska & Psychiatric Residential Rehabilitation Center_Adults & 7 & 10 & 75 \\
\hline Nevada & Group Homes for Adults & 64 & 5 & 849 \\
\hline New Jersey & Group Homes for Adults & 159 & 6 & 1,054 \\
\hline \multirow[t]{3}{*}{ New York } & Impacted Adult Homes & 219 & 67 & 17,347 \\
\hline & Community Residential Programs for Adults & 532 & 21 & 11,248 \\
\hline & Community-Based Family Care Homes & 560 & 3 & 2,000 \\
\hline North Carolina & Supervised Living Facilities for Adults & 184 & 6 & 816 \\
\hline \multirow[t]{2}{*}{ Oklahoma } & Residential Care Homes for Adults & 102 & 32 & 3,218 \\
\hline & Enhanced Residential Care Homes for Adults & 3 & 26 & 77 \\
\hline \multirow[t]{2}{*}{ Oregon } & Intensive Foster Care for Adults & 100 & 4 & 447 \\
\hline & Residential Treatment Facilities for Adults & 53 & 14 & 722 \\
\hline \multirow[t]{2}{*}{ Pennsylvania } & Long-Term Structured Residential Facilities for Adults & 25 & 14 & 359 \\
\hline & $\begin{array}{l}\text { Community Residential Rehabilitation Group Homes for } \\
\text { Adults }\end{array}$ & 545 & 5 & 2,726 \\
\hline Rhode Island & Adult Group Homes & 24 & 8 & 212 \\
\hline \multirow[t]{2}{*}{ South Carolina } & Level II Community Residential Care Facilities & 24 & 14 & 340 \\
\hline & Structured Community Residential Care Facilities & 17 & 9 & 159 \\
\hline \multirow[t]{2}{*}{ Tennessee } & Mental Health Supportive Living Facilities & 231 & 9 & 2,141 \\
\hline & Mental Health Adult Residential Treatment & 8 & 9 & 74 \\
\hline Utah & Residential Treatment Facilities_-Adult & 41 & 17 & 843 \\
\hline Virginia & Adult Group Homes & 26 & 6 & 154 \\
\hline Washington & Adult Residential Treatment Facilities & 18 & 27 & 492 \\
\hline West Virginia & Residential Facilities Serving the Adult Mentally III & 12 & 9 & 103 \\
\hline \multirow[t]{2}{*}{ Wisconsin } & Adult Family Homes & 740 & 4 & 2,864 \\
\hline & Community-Based Residential Facilities & 1,373 & 16 & 21,843 \\
\hline Wyoming & Adult Group Homes & 4 & 7 & 24 \\
\hline Total & 63 Facilities & 7,327 & - & 103,393 \\
\hline
\end{tabular}


outpatient mental health clinics, psychiatric hospitals, general hospitals with separate psychiatric services, and other mental health organizations. Other mental health organizations include freestanding psychiatric outpatient clinics, freestanding partial care organizations, and multiservice mental health organizations, which are organizations that provide services in both 24-hour and lessthan-24-hour settings and are not classifiable to other organizations such as psychiatric hospitals. Overall, the SMHO focuses on counting organizations whose primary mission is to provide clinical mental health services.

The present study has a different focus from the focus of the SMHO, and leads to the inclusion of a wider range of facilities. For example, Louisiana has developed regulations for a type of facility called "supportive housing apartments for adults.” In 2003, this facility type had 15 licensed facilities, with an average of 20 persons per facility. The maximum length of stay is 5 years for residents in facilities within this facility type, with an average of 2 years. Facilities are required to provide training in activities of daily living, case management, and medication management. Formal counseling services are not provided. Although the survey data from the present study does not indicate whether any of these facilities are owned by mental health organizations as defined by the SMHO, it is possible that these facilities and their associated beds would not be included in the SMHO count.

It is also useful to compare results from the present study with data from NASMHPD's State profiles, as illustrated in Table III.2. As this comparison shows, for most of the States that provided data in both studies, the number of beds identified in the present study either exceeds or is close to the number of beds identified in NASMHPD's State profiles. For example, in the present study, Connecticut reported that it had developed regulations for facility types that included facilities with a total number of 3,025 beds as of September 2003, whereas in the State profile data, Connecticut reported 1,176 beds in facilities funded and operated by State mental health agencies on the last day of fiscal year 2002. Again, the difference is likely to result from the fact that the present study includes a greater number of facilities (and therefore a greater number of associated beds) because it incorporates facilities beyond those that are funded and operated by State mental health agencies. Delaware and Rhode Island are exceptions to the pattern, and the reasons for this finding may involve reporting error, the differences in the time period between the studies, or some other factors.

In summary, in contrast to data from the SMHO and the profiles developed by the NASMHPD Research Institute, the present

\begin{tabular}{|c|c|c|}
\hline \multicolumn{3}{|c|}{$\begin{array}{l}\text { Table III.2. Number of Beds in } \\
\text { Residential Facilities for Selected } \\
\text { States for Selected Months as } \\
\text { Reported in Two Data Sources }\end{array}$} \\
\hline \multirow[b]{2}{*}{ State } & \multicolumn{2}{|c|}{ Number of Beds as Reported in the } \\
\hline & $\begin{array}{c}\text { Present } \\
\text { Study* }\end{array}$ & $\begin{array}{l}\text { NASMHPD's } \\
\text { Profiles*** }\end{array}$ \\
\hline Connecticut & 3,025 & 1,176 \\
\hline Delaware & 138 & 180 \\
\hline Hawaii & 272 & 240 \\
\hline New York & 30,595 & 6,914 \\
\hline Oklahoma & 3,295 & 199 \\
\hline Oregon & 1,169 & 1,186 \\
\hline Rhode Island & 212 & 314 \\
\hline South Carolina & 499 & 30 \\
\hline Utah & 843 & 459 \\
\hline \multicolumn{3}{|c|}{$\begin{array}{l}\text { Sources: Data from the present study are drawn from surveys } \\
\text { submitted by State officials. Data from the NASMHPD's } \\
\text { profiles can be found at www.nni-inc.org. }\end{array}$} \\
\hline \multicolumn{3}{|c|}{$\begin{array}{l}{ }^{*} \text { As of September } 30,2003 . \\
{ }^{*} \text { As of last day of fiscal year } 2002 .\end{array}$} \\
\hline
\end{tabular}


study was designed specifically to examine methods that States use to regulate residential facilities that meet the criteria listed in Table III.1. These criteria led to the inclusion of a wide range of facilities, including facilities that would not be counted in the SMHO data or the NASMHPD's State profiles. Because it included more residential facility types, the present study also includes a greater number of beds.

\section{B. Average Number of Residents}

Approximately 39 percent of the facilities averaged between 3 and 8 residents (see Table III.3). Another 40 percent of the facilities had an average of 9 to 16 residents. Only about 19 percent of facilities averaged
17 or more residents. For the facility types for which States were able to report occupancy rate information, rates ranged from 42 to 100 percent, although the rate for most was 85 percent or higher.

\section{Average Length of Stay}

Length of stay is an important characteristic of a residential facility because of concerns that long lengths of stay are associated with more difficulty in returning to self-sufficient, independent living after discharge. However, many States do not appear to collect data on average length of stay. States were unable to provide the average length of stay for 38 percent of facility types and 43 percent of facilities (see Table III.4).

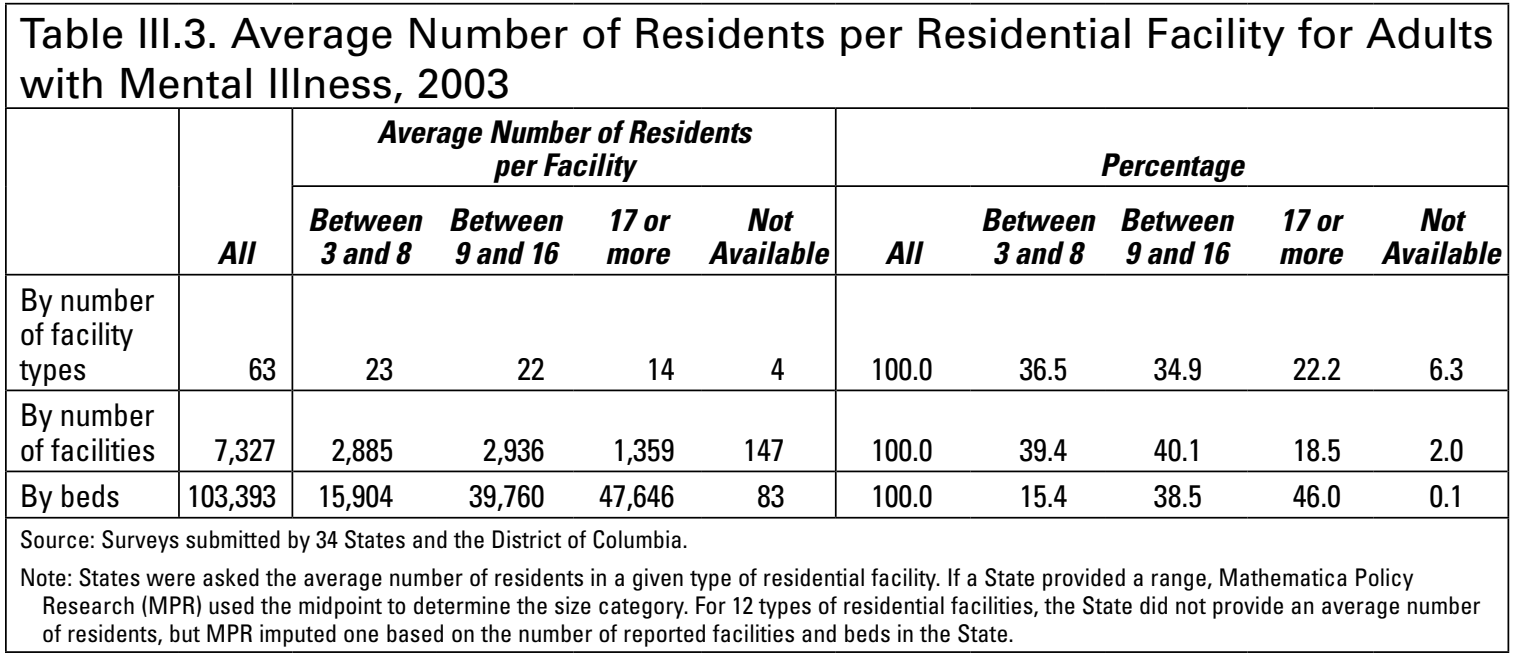

Table III.4. Average Length of Stay in Residential Facilities for Adults with Mental Illness, by Number of Facilities, 2003

\begin{tabular}{|l|c|c|c|c|c|c|}
\hline & \multicolumn{2}{|c|}{ Facility Type } & \multicolumn{2}{c|}{ Facilities } & \multicolumn{2}{c|}{ Beds } \\
\cline { 2 - 7 } & Number & Percentage & Number & Percentage & Number & Percentage \\
\hline 1-6 months & 11 & 17.5 & 638 & 8.7 & 8,643 & 8.5 \\
7-12 months & 6 & 9.5 & 138 & 1.9 & 4,709 & 4.6 \\
13 or more months & 22 & 34.9 & 3,426 & 46.8 & 47,122 & 45.5 \\
Data unavailable & 24 & 38.1 & 3,125 & 42.7 & 42,919 & 41.5 \\
Total & 63 & 100.0 & 7,327 & 100.0 & 103,393 & 100.0 \\
\hline
\end{tabular}


Average lengths of stay longer than 1 year were common. Nearly 47 percent of facilities had an average length of stay of more than 1 year.

Eight of the 63 types of facilities (accounting for just 1 percent of the total number of facilities) were subject to a State-mandated maximum length of stay. In these facilities, the maximum ranged from 3 to 18 months.

\section{Organizations that Operate Residential Facilities}

The types of organization that operate residential facilities for adults with mental illness may vary within facility type. The survey asked States to indicate what percentage of facilities within a particular facility type were operated by selected ownership arrangements (i.e., not-for-profit, for-profit, State or local government). Facility types were then classified by the dominant ownership arrangement, defined as the type of organization operating 75 percent or more of facilities within a facility type.

The majority of facilities were predominantly or wholly operated by not-for-profit organizations (see Table III.5). States reported that facilities in 30 of the 63 facility types were predominantly or wholly operated by not-for-profit organizations. In contrast, State and local governments operated only a small share of residential facilities. States reported that State or local governments predominantly or wholly owned facilities in just 4 facility types. States were unable to report ownership information for 6 facility types, or 10 percent.

\section{E. Secure Units}

The study found that a very small number of facility types (8) were allowed to have locked units under State regulations. Moreover, just because a type of residential facility was allowed to have locked units did not necessarily mean that all facilities within that type had them. In many cases, respondents indicated that fewer than 50 percent of facilities within a facility type allowed to have locked units actually had these units. The survey did not gather information on the number of beds in locked units in facilities that were allowed to have locked units.

Larger facilities were more likely than smaller facilities to be allowed to have locked units. Five of the 18 facility types with more than 16 residents were allowed to have locked units as compared with no facility types whose average number of residents ranged from 3 to 8 .

\section{Table III.5. Ownership of Residential Facilities for Adults with Mental Illness, by Number of Facilities, 2003}

\begin{tabular}{|c|c|c|c|c|c|c|}
\hline & \multicolumn{2}{|c|}{ Facility Type } & \multicolumn{2}{|c|}{ Facilities } & \multicolumn{2}{|c|}{ Beds } \\
\hline & Number & $\begin{array}{c}\text { Percent- } \\
\text { age }\end{array}$ & Number & $\begin{array}{c}\text { Percent- } \\
\text { age }\end{array}$ & Number & $\begin{array}{l}\text { Percent- } \\
\text { age }\end{array}$ \\
\hline Wholly or predominantly operated by not-for-profit organizations & 30 & 47.6 & 3,129 & 42.7 & 32,880 & 31.9 \\
\hline Wholly or predominantly operated by for-profit organizations & 7 & 11.1 & 420 & 5.7 & 9,355 & 9.0 \\
\hline Wholly or predominantly operated by State or local government & 4 & 6.4 & 645 & 8.8 & 2,885 & 2.8 \\
\hline Wholly or predominantly operated by other entities & 1 & 1.6 & 71 & 1.0 & 2,360 & 2.3 \\
\hline Varied ownership & 15 & 23.8 & 910 & 12.4 & 27,309 & 26.4 \\
\hline Ownership information not available & 6 & 9.5 & 2,152 & 29.4 & 28,604 & 27.6 \\
\hline Total & 63 & 100.0 & 7,327 & 100.0 & 103,393 & 100.0 \\
\hline
\end{tabular}




\section{State Oversight: Requirements,}

Licensing, Regulations

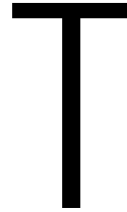

o regulate standards of care received by residents of facilities for adults with mental illness, many States stipulate basic requirements for, among other aspects of care, minimum staff-to-resident ratios, minimum education of facility directors, and requirements for reporting critical events to the State. In addition, States rely on several agencies to license, monitor, and review complaints against residential facilities for adults with mental illness. In many States, more than one agency is responsible for these tasks. This chapter presents findings in the following areas:

- Basic requirements for facilities

- Licensing agencies

- Monitoring practices

- Agencies reviewing complaints

- Accreditation requirements

\section{A. Basic Requirements for Facilities}

States have varied laws or regulations that govern operational requirements for residential facilities for adults with mental illness. Three requirements frequently included in these State laws involve staff-to-resident ratios, minimum education requirements for facility directors, and requirements for reporting critical events to the State.

\section{Staff-to-Resident Ratio Requirements} Thirty-six of the 63 facility types (57 percent) captured by the survey were subject to State requirements for staff-to-resident ratios during daytime hours (see Table
IV.1). These types accounted for 25 percent of the total number of facilities and 30 percent of beds. Among those types with a requirement, about a third had a requirement that there could be no more than 5 to 8 residents per staff person during daytime hours; for approximately another third, the ratio was 9 or higher.

Staff-to-resident ratio requirements were more common in larger facilities. About 43 percent of larger residential facilities (17 or more residents) were subject to a staff-to-resident ratio requirement as compared with 16 percent of facilities with an average of 3 to 8 residents. 


\begin{tabular}{|c|c|c|c|c|c|c|}
\hline & \multicolumn{2}{|c|}{ Facility Type } & \multicolumn{2}{|c|}{ Facilities } & \multicolumn{2}{|c|}{ Beds } \\
\hline & Number & $\begin{array}{l}\text { Percent- } \\
\text { age }\end{array}$ & Number & $\begin{array}{l}\text { Percent- } \\
\text { age }\end{array}$ & Number & $\begin{array}{c}\text { Percent- } \\
\text { age }\end{array}$ \\
\hline $\begin{array}{l}\text { State-mandated staff-to-resident ratio } \\
\text { Of those with a requirement: }\end{array}$ & 36 & 57.1 & 1,832 & 25.0 & 31,462 & 30.4 \\
\hline 1 staff to $2-4$ residents & 6 & 18.8 & 56 & 3.1 & 1,692 & 5.4 \\
\hline 1 staff to 5-8 residents & 12 & 33.3 & 735 & 40.1 & 9,301 & 29.6 \\
\hline 1 staff to 9 or more residents & 13 & 36.1 & 603 & 32.9 & 11,081 & 35.2 \\
\hline Other requirement* & 1 & 2.8 & 70 & 3.8 & $\mathrm{~N} / \mathrm{A}$ & N/A \\
\hline Information not provided & 4 & 11.1 & 368 & 20.1 & 9,388 & 29.8 \\
\hline \multicolumn{7}{|c|}{ Source: Surveys submitted by 34 States and the District of Columbia. } \\
\hline $\begin{array}{l}\text { Note: This table presents information on daytime } \\
\text { (i.e., a single staff member is responsible for m } \\
\text { *Requirement does not set specific ratio. Require }\end{array}$ & $\begin{array}{l}\text { ff-to-resident r } \\
\text { residents). N/ } \\
\text { nt mandates o }\end{array}$ & $\begin{array}{l}\text { s. Survey } \\
\text { dicates de }\end{array}$ & $\begin{array}{l}\text { ticate tha } \\
\text { vvailable. }\end{array}$ & & & ly higher \\
\hline
\end{tabular}

\section{Minimum Education of Facility Directors}

Fifty-six percent of facility types, accounting for 52 percent of facilities, were subject to a State requirement mandating a minimum level of education for the facility director (see Table IV.2). Among those facilities with a requirement, 62 percent of facilities accounting for 79 percent of beds had a requirement for less than a bachelor's degree, generally an associate's degree. Twentysix percent of facilities were subject to a requirement that the facility director must hold at least a bachelor's degree and, in 3 percent of facilities, the director must hold a master's degree.

\section{Critical Incident Reporting Requirements}

Reports of critical incidents, such as a death, suicide attempt, or hospitalization of a resident, were used by numerous States to monitor facility operations. States indicated that most facility types were required to report critical events that affect the health and safety of residents (see Table IV.3).

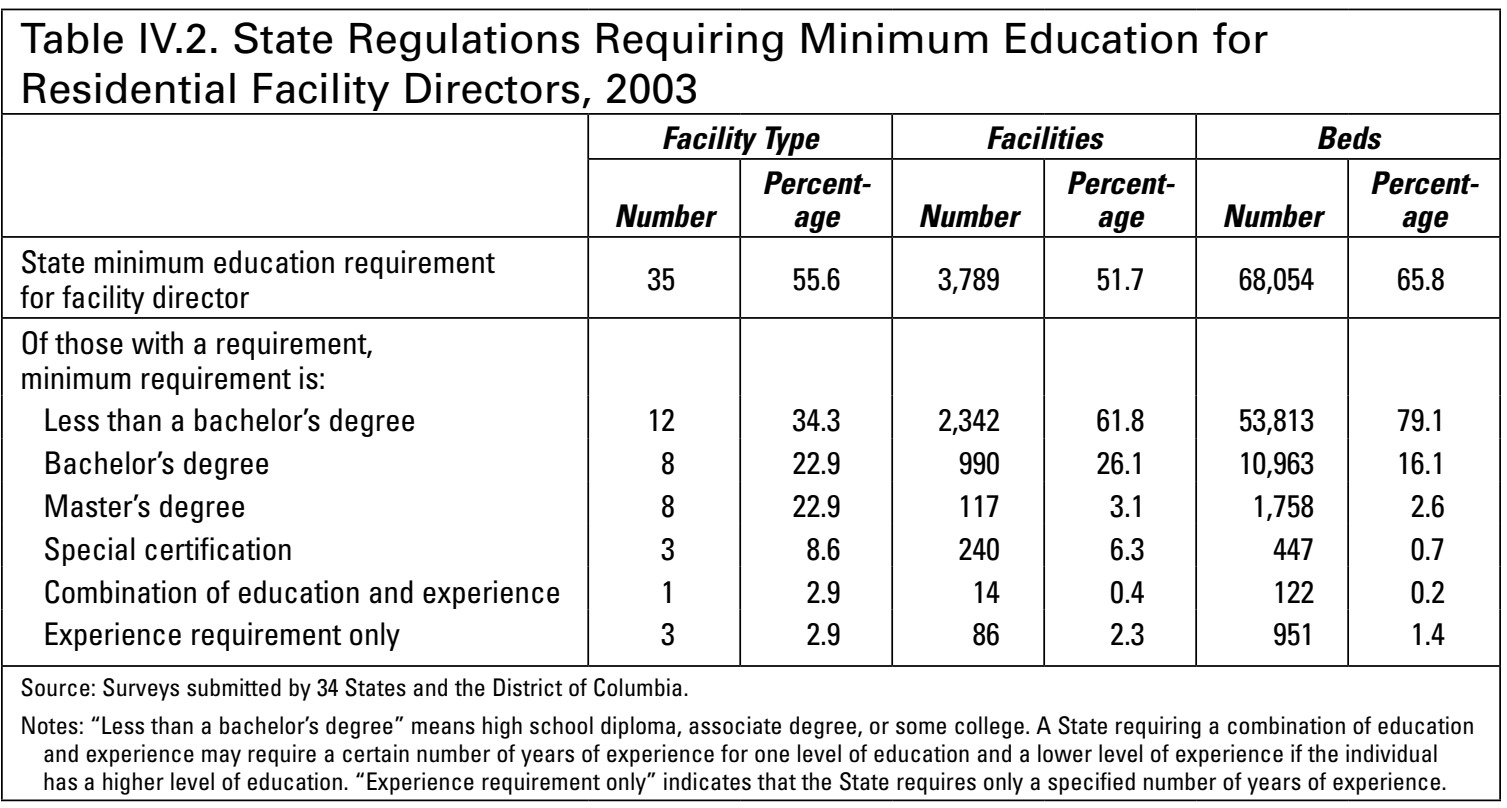




\begin{tabular}{|c|c|c|c|c|c|c|}
\hline \multirow[b]{2}{*}{ Critical Incidents } & \multicolumn{2}{|c|}{ Facility Types } & \multicolumn{2}{|c|}{ Facilities } & \multicolumn{2}{|c|}{ Beds } \\
\hline & Number & Percentage & Number & Percentage & Number & Percentage \\
\hline Death & 55 & 87.3 & 6,437 & 87.9 & 91,511 & 88.5 \\
\hline Suicide & 56 & 88.9 & 6,698 & 91.4 & 97,596 & 94.4 \\
\hline Suicide attempt & 46 & 73.0 & 4,025 & 54.9 & 64,655 & 62.6 \\
\hline Allegations of abuse or neglect & 53 & 84.1 & 6,411 & 87.5 & 91,260 & 88.3 \\
\hline Hospitalization of a resident & 23 & 36.5 & 3,350 & 45.7 & 39,125 & 37.8 \\
\hline
\end{tabular}

States indicated that facilities were required to report resident deaths in 55 of the 63 facility types ( 87 percent). Suicide attempts were to be reported in 46 of the facility types (73 percent). Fewer facilities were required to report the hospitalization of a resident. Twenty-three of the 63 facility types were required to report resident hospitalizations, which accounted for 46 percent of facilities and 38 percent of beds.

\section{B. Licensing Agencies}

The survey found that, depending on the particular State, several types of agencies licensed or certified residential facilities for adults with mental illness. Agencies included the State mental health authority, State department of health, and State department of social services.

In some cases, more than one State agency was involved in licensing or certifying resi- dential facilities for adults with mental illness. In 23 of the 63 facility types (37 percent), the State reported that two agencies were involved in licensing and/or certification (see Table IV.4). For example, in California, many of the facility types must be licensed by the State department of social services and receive certification from the State mental health authority. Two States did not require a license or certification, although they did exercise some oversight authority through monitoring visits or other means.

For the majority of facility types (34 of the 63), the State mental health authority had some role in licensing or certifying each residential facility (see Table IV.5). A number of States also cited the State department of health, which had some licensing or certification role for 37 percent of facility types, 43 percent of facilities, and 55 percent of residential beds.

\begin{tabular}{|c|c|c|c|c|c|c|}
\hline \multirow[b]{2}{*}{ Number of Agencies } & \multicolumn{2}{|c|}{ Facility Types } & \multicolumn{2}{|c|}{ Facilities } & \multicolumn{2}{|c|}{ Beds } \\
\hline & Number & Percentage & Number & Percentage & Number & Percentage \\
\hline Zero* & 2 & 3.2 & 109 & 1.5 & 934 & 1.0 \\
\hline One & 38 & 60.3 & 6,117 & 83.5 & 88,829 & 85.8 \\
\hline Two & 23 & 36.5 & 1,101 & 15.0 & 13,630 & 13.2 \\
\hline Total & 63 & 100.0 & 7,327 & 100.0 & 103,393 & 100.0 \\
\hline
\end{tabular}




\section{Table IV.5. State Agencies Involved in Licensure or Certification of Residential Facilities for Adults with Mental IIIness, 2003}

\begin{tabular}{|c|c|c|c|c|c|c|}
\hline & \multicolumn{2}{|c|}{ Facility Types } & \multicolumn{2}{|c|}{ Facilities } & \multicolumn{2}{|c|}{ Beds } \\
\hline & Number & Percentage & Number & Percentage & Number & Percentage \\
\hline State mental health authority & 34 & 54.0 & 3,601 & 49.2 & 38,545 & 37.2 \\
\hline Local mental health agency & 8 & 12.7 & 654 & 8.9 & 5,921 & 5.7 \\
\hline Department of social services & 5 & 7.9 & 141 & 1.9 & 2,140 & 2.1 \\
\hline Department of health & 23 & 36.5 & 3,112 & 42.5 & 57,340 & 55.4 \\
\hline $\begin{array}{l}\text { Department of health and } \\
\text { human services }\end{array}$ & 4 & 6.4 & 469 & 6.4 & 7,099 & 6.9 \\
\hline Department of human services & 2 & 3.2 & 190 & 2.6 & 2,943 & 2.8 \\
\hline Other & 8 & 12.7 & 152 & 2.1 & 2,101 & 2.0 \\
\hline
\end{tabular}

\section{Regulatory Practices}

The study found that to obtain licenses or certifications, States often required facilities to undergo a review that could involve a site visit, record review, documentation of staff qualification and training, or other procedures. In nearly all facility types, the State required a site inspection before issuing a license or certification (see Table IV.6). About 94 percent of facilities were required to have a site inspection. Slightly fewer (90 percent) were required to undergo a site inspection in order to renew their license or certification. Resident interviews were the least commonly required activity. Forty-one percent of facility types, accounting for 55 percent of residential facilities, had a resident interview requirement for either licensure or certification. Those numbers increased somewhat, to 59 percent of facility types and 73 percent of facilities, at renewal. Resident interviews were

\section{Table IV.6. Procedures Required by States for Initial Licensure or Certification and Renewal of Licensure or Certification for Residential}

Facilities for Adults with Mental IIIness, 2003

\begin{tabular}{|c|c|c|c|c|c|c|c|}
\hline & \multicolumn{2}{|c|}{ Facility Types } & \multicolumn{2}{|c|}{ Facilities } & \multicolumn{2}{|c|}{ Beds } \\
\hline & & Number & Percentage & Number & Percentage & Number & Percentage \\
\hline \multirow{2}{*}{$\begin{array}{l}\text { Onsite } \\
\text { inspection }\end{array}$} & Initial & 59 & 93.7 & 6,935 & 94.7 & 84,263 & 81.4 \\
\hline & Renewal & 55 & 87.3 & 6,619 & 90.3 & 93,418 & 90.3 \\
\hline \multirow{2}{*}{$\begin{array}{l}\text { Documentation of } \\
\text { staff qualifications }\end{array}$} & Initial & 49 & 77.8 & 5,227 & 71.3 & 69,647 & 67.3 \\
\hline & Renewal & 44 & 69.8 & 4,075 & 55.6 & 48,612 & 47.0 \\
\hline \multirow{2}{*}{$\begin{array}{l}\text { Documentation } \\
\text { of staff training }\end{array}$} & Initial & 37 & 58.7 & 4,118 & 56.2 & 56,224 & 54.4 \\
\hline & Renewal & 41 & 65.1 & 3,997 & 54.6 & 44,658 & 43.2 \\
\hline \multirow{2}{*}{$\begin{array}{l}\text { Record } \\
\text { review }\end{array}$} & Initial & 43 & 68.3 & 5,780 & 78.9 & 61,499 & 59.4 \\
\hline & Renewal & 50 & 79.4 & 6,685 & 91.2 & 94,131 & 91.0 \\
\hline \multirow{2}{*}{$\begin{array}{l}\text { Resident } \\
\text { interviews }\end{array}$} & Initial & 26 & 41.3 & 3,993 & 54.5 & 44,834 & 43.3 \\
\hline & Renewal & 37 & 58.7 & 5,326 & 72.7 & 80,762 & 78.0 \\
\hline
\end{tabular}


not usually required for the initial license or certification because before the facility opens there are no residents to interview.

Announced and unannounced visits to facilities also were a common practice in monitoring facility performance and were used to assess living conditions, safety issues, and services provided. In 41 of the 63 types of residential facilities identified by States, States conducted unannounced visits for monitoring purposes to at least some facilities within the given facility type. States conducted announced visits to 44 of the 63 facility types. For three facility types, States indicated that they did not conduct any announced or unannounced visits.

Although monitoring visits were common, the percentage of facilities that received a visit in 2003 varied significantly by facility type. In some cases, a State visited just 1 percent of facilities within a facility type; in other cases, the State visited all of the facilities.

\section{Agencies Responsible for Reviewing Complaints}

The survey found that in many cases, more than one State agency or office was responsible for reviewing complaints against facilities (see Table IV.7). According to survey respondents, more than one agency reviewed complaints against 32 percent of residential facilities whereas three or more agencies were responsible for reviewing complaints against 9 percent of facilities.

Just as with licensing and certification, States most often cited the State mental health agency and the State department of health as the agencies responsible for reviewing complaints against facilities (see Table IV.8). The State mental health agency was at least one of the agencies responsible for reviewing complaints against two-thirds of the facility types included in the study, accounting for slightly more than half (53 percent) of all facilities. The department of health reviewed complaints for about 30 percent of facility types, accounting for about 41 percent of all facilities.

In addition to the agencies listed in Table IV.8, States mentioned that the following State entities reviewed complaints: a human rights advocacy group, a long-term health care ombudsman, and the Medicaid agency.

\section{E. Accreditation}

In addition to requiring licensure or certification, a few States required residential facilities to be accredited by one of the national accrediting organizations. About 5 percent of the residential facilities captured by the

\begin{tabular}{|c|c|c|c|c|c|c|}
\hline \multirow[b]{2}{*}{ Number of Agencies } & \multicolumn{2}{|c|}{ Facility Types } & \multicolumn{2}{|c|}{ Facilities } & \multicolumn{2}{|c|}{ Beds } \\
\hline & Number & Percentage & Number & Percentage & Number & Percentage \\
\hline Not available & 2 & 3.2 & 46 & 0.6 & 1,909 & 1.8 \\
\hline One & 22 & 34.9 & 4,961 & 67.7 & 59,521 & 57.6 \\
\hline Two & 27 & 42.8 & 1,669 & 22.8 & 35,429 & 34.2 \\
\hline Three & 9 & 14.3 & 578 & 7.9 & 5,859 & 5.7 \\
\hline Four & 3 & 4.8 & 73 & 1.0 & 675 & 0.7 \\
\hline Total & 63 & 100.0 & 7,327 & 100.0 & 103,393 & 100.0 \\
\hline
\end{tabular}




\begin{tabular}{|c|c|c|c|c|c|c|}
\hline \multicolumn{7}{|c|}{$\begin{array}{l}\text { Table IV.8. State Agencies that Review Complaints Against Residential } \\
\text { Facilities for Adults with Mental IIIness, } 2003\end{array}$} \\
\hline & \multicolumn{2}{|c|}{ Facility Types } & \multicolumn{2}{|c|}{\begin{tabular}{|c|} 
Facilities \\
\end{tabular}} & \multicolumn{2}{|c|}{ Beds } \\
\hline & Number & Percentage & Number & Percentage & Number & Percentage \\
\hline State mental health authority & 42 & 66.7 & 3,889 & 53.1 & 42,348 & 41.0 \\
\hline Local mental health agency & 16 & 25.4 & 1,470 & 20.1 & 16,121 & 15.6 \\
\hline Department of children and families & 6 & 9.5 & 215 & 2.9 & 4,433 & 4.3 \\
\hline Department of social services & 6 & 9.5 & 247 & 3.4 & 3,099 & 3.0 \\
\hline Department of health & 19 & 30.2 & 3,037 & 41.5 & 49,252 & 47.6 \\
\hline Department of health and human services & 3 & 11.1 & 285 & 19.2 & 6,283 & 17.6 \\
\hline Department of human services & 5 & 18.5 & 529 & 35.7 & 5,605 & 15.7 \\
\hline Other & 19 & 70.4 & 668 & 45.1 & 23,831 & 66.7 \\
\hline
\end{tabular}

survey were required to obtain accreditation from a national accrediting organization.

Some of the accrediting organizations listed by respondents were the Joint Commission on Accreditation of Healthcare Organizations, the Commission on Accreditation of Rehabilitation
Facilities, the Council on Accreditation for Children and Family Services, the Utilization Review Accreditation Commission, and the National Committee for Quality Assurance. Generally, facilities were allowed to choose which organization would provide their accreditation. 


\section{Services and Financing}

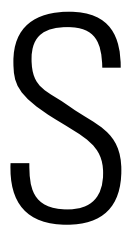

tates vary considerably in terms of the services that residential facilities for adults with mental illness are required to provide to residents. Whereas some facilities are required to provide any service identified in an individual's treatment plan, other facilities are required to do little more than manage medication. This chapter describes the services provided by residential facilities for adults with mental illness and the funding sources for the facilities.

\section{A. Services Provided}

As Table V.1 shows, the most common services provided in the residential facilities covered by the survey were assistance with activities of daily living (provided in 95 percent of facilities), training in activities of daily living (88 percent of facilities), and medication management ( 87 percent of facilities). The least frequently provided service was occupational therapy, which just 6 percent of residential facilities were required to provide. Generally, States reported that facilities were required to provide more in the way of personal care services than clinical programs.

Individual counseling was required in 34 facility types (54 percent), which represented about 57 percent of all facilities and beds. Medication management was required in 79 percent of facility types, accounting for 87 percent of facilities and 92 percent of residential beds.

A majority of facilities, 60 percent, were required by the State to complete a comprehensive discharge plan when a client leaves a facility. About 46 percent of facilities were required to provide either discharge medica- tions or a specific medication plan when a client left the facility. The least commonly required discharge service was a followup visit at the client's next residence. Only 1 percent of facilities were required to conduct a followup visit.

\section{B. Funding Sources}

Facilities appeared to draw funds from a variety of funding sources (see Table V.2), indicating that they provided care to individuals who were involved with many different State, local, and private programs and health insurance plans. According to the survey results, State and local mental health agencies were the most common funding source for facilities for adults with mental illness. Fifty of the 63 facility types (79 percent) typically received at least some funding from the State or local mental health agency. These 50 facility types accounted for 84 percent of facilities and 64 percent of beds reported by States. Federal income assistance programs were also a common funding source. Supplemental Security Income payments were a funding source in about 70 percent of facility types and 84 percent of 


\begin{tabular}{|c|c|c|c|c|c|c|}
\hline & \multicolumn{2}{|c|}{ Facility Type } & \multicolumn{2}{|c|}{ Facilities } & \multicolumn{2}{|c|}{ Beds } \\
\hline & Number & Percentage & Number & Percentage & Number & Percentage \\
\hline Counseling Services & & & & & & \\
\hline Individual counseling & 34 & 54.0 & 4,199 & 57.3 & 59,330 & 57.4 \\
\hline Group counseling & 24 & 38.1 & 1,475 & 20.1 & 22,317 & 21.6 \\
\hline Family counseling & 19 & 30.2 & 1,306 & 17.8 & 16,933 & 16.4 \\
\hline Financial management counseling & 26 & 41.3 & 5,223 & 71.3 & 59,817 & 57.9 \\
\hline Medication Services & & & & & & \\
\hline Medication management & 50 & 79.4 & 6,346 & 86.6 & 95,077 & 92.0 \\
\hline Dispensing of medication & 39 & 61.9 & 5,230 & 71.4 & 70,761 & 68.4 \\
\hline Education and Training Services & & & & & & \\
\hline Education & 21 & 33.3 & 2,029 & 27.7 & 30,413 & 29.4 \\
\hline Assistance with ADLs & 46 & 73.0 & 6,925 & 94.5 & 97,046 & 93.9 \\
\hline Training in ADLs & 46 & 73.0 & 6,428 & 87.7 & 69,936 & 67.7 \\
\hline Vocational training & 22 & 34.9 & 1,908 & 26.0 & 31,936 & 31.0 \\
\hline Occupational therapy & 10 & 15.9 & 459 & 6.3 & 6,237 & 6.0 \\
\hline Case Management/Advocacy & & & & & & \\
\hline Case management & 33 & 52.4 & 4,968 & 67.8 & 76,617 & 74.1 \\
\hline Client advocacy & 30 & 47.6 & 5,272 & 72.0 & 66,664 & 64.5 \\
\hline Discharge Services & & & & & & \\
\hline Comprehensive discharge plan & 39 & 61.9 & 4,371 & 59.7 & 64,460 & 62.3 \\
\hline $\begin{array}{l}\text { Discharge medications or } \\
\text { medication plan }\end{array}$ & 23 & 36.5 & 3,384 & 46.2 & 59,242 & 57.3 \\
\hline Followup plan & 9 & 14.3 & 870 & 11.9 & 9,950 & 9.6 \\
\hline Discharge interview or satisfaction survey & 11 & 17.5 & 892 & 12.2 & 10,634 & 10.3 \\
\hline Followup visit at home/other residence & 4 & 6.4 & 92 & 1.3 & 983 & 1.0 \\
\hline
\end{tabular}

facilities. Social Security Disability Insurance payments were a funding source in 59 percent of facility types, accounting for 47 percent of facilities and 54 percent of beds.

Medicaid was a funding source in just 26 of the 63 facility types, accounting for 65 percent of facilities and 55 percent of beds. Medicaid's restrictions on services for adults between ages 22 and 64 may be the reason that many facilities did not appear to receive Medicaid funding. Facilities with more than 16 residents were probably designated as an institution for mental diseases and therefore not eligible for Medicaid funds; many facilities with 16 or fewer residents also did not qualify for coverage under Medicaid. For those facility types where Medicaid was indicated as a funding source, the State was asked to provide the average Medicaid per diem for the facility type. Of the eight facility types for which States were able to provide an answer, the average per diem ranged from $\$ 10$ to $\$ 300$. Half had per diems of more than $\$ 100$ per day. 
Table V.2. Funding Sources for Residential Facilities for Adults with Mental IIIness, 2003

\begin{tabular}{|l|c|c|c|c|c|c|}
\hline & Facility Types & \multicolumn{2}{|c|}{ Facilities } & \multicolumn{2}{c|}{ Beds } \\
\cline { 2 - 7 } & Number & $\begin{array}{c}\text { Percent- } \\
\text { age }\end{array}$ & Number & $\begin{array}{c}\text { Percent- } \\
\text { age }\end{array}$ & Number & $\begin{array}{c}\text { Percent- } \\
\text { age }\end{array}$ \\
\hline State/local mental health agency & 50 & 79.4 & 6,149 & 83.9 & 65,824 & 63.7 \\
Supplemental Security Income (SSI) payments & 44 & 69.8 & 6,123 & 83.6 & 84,741 & 82.0 \\
Social Security Disability Insurance (SSDI) payments & 37 & 58.7 & 3,434 & 46.9 & 55,684 & 53.9 \\
Self-pay & 35 & 55.6 & 5,112 & 69.8 & 71,602 & 69.2 \\
Medicaid & 26 & 41.3 & 4,732 & 64.6 & 57,097 & 55.2 \\
Other third party & 27 & 42.9 & 3,319 & 45.3 & 53,902 & 52.1 \\
State Supplemental Payment (SSP) & 15 & 23.8 & 1,977 & 27.0 & 38,771 & 37.5 \\
Federal grants & 11 & 17.5 & 341 & 4.7 & 5,388 & 5.2 \\
Private grants & 10 & 15.9 & 316 & 4.3 & 5,334 & 5.2 \\
State welfare payments & 5 & 7.9 & 393 & 5.4 & 17,539 & 17.0 \\
Department of defense & 3 & 4.8 & 324 & 4.4 & 20,642 & 20.0 \\
Department of child and family services & 4 & 6.4 & 2,273 & 31.0 & 26,133 & 25.3 \\
Department of education & 1 & 1.6 & 44 & 0.6 & 514 & 0.5 \\
\hline Source: Surveys submitted by 34 States and the District of Columbia. & & & & &
\end{tabular}





\section{Conclusions}

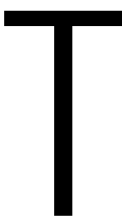

his study provides new information on methods that States use to monitor residential facilities for adults with mental illness. The findings underscore the substantial variation across States in the regulatory methods they employ to monitor residential facilities for adults with mental illness. The study found that although all States use at least several regulatory methods, no State uses all of the possible methods, which include a wide range of specifications and requirements, such as

- Requirements for announced and unannounced visits

- Mandated staff-to-resident ratios

- Requirements for minimum levels of education for facility directors

- Requirements for continuing education for direct care staff

- Specifications for critical-incident reporting

- Specific licensing practices

- Mandated complaint-review procedures

- Accreditation from designated State or national organizations

States differ widely in the types of residential facilities that they regulate. Some States, for example, have developed regulations for facility types that include only small facilities whereas other States have focused on regulating larger congregate settings. Some States regulate facilities that provide a limited number of therapeutic services beyond room and board; other States regulate facilities that offer a comprehensive set of counseling activities. The types of facilities that States regulate differ along numerous dimensions, such as mission, administrative structure, size, ownership arrangements, typical length of stay, services provided, and mix of funding sources. States also refer to facilities by different names, making it difficult to identify the extent to which facilities in different States are similar.

The study findings demonstrate that the organizations that operate facilities for adults with mental illness typically face a complex regulatory environment. A wide variety of State agencies with different missions and functions, including State mental health authorities, departments of health, and departments of social services, oversee these residential facilities. For 61 percent of the types of residential facilities covered by the survey, two or more State agencies are involved in reviewing complaints, and for 37 percent of all facility types, licenses or certification are required from more than one agency.

At the State level, the study showed that many States lack ready access to important data about residential facilities for adults with mental illness. For example, about 40 percent of respondents were unable to provide information on the average length of stay in the facilities they were overseeing, and respondents could not provide 
ownership information for about 10 percent of facility types, accounting for almost 30 percent of facilities. Moreover, respondents often indicated that they were relying on administrative estimates rather than specific records or documents to report on certain types of descriptive data such as average number of residents per facility, frequency of announced visits, or Medicaid per diems.

Finally, although the present study was not designed to provide a national count of residential facilities for adults with mental illness, its results on the number of facilities for adults with mental illness and associated beds can be compared with data from other studies, such as studies based on SMHO data (see, for example, Manderscheid et al., 2004). Because of its focus on regulatory methods, the present study covered a wider range of residential settings than did the $\mathrm{SMHO}$, and hence it identified a larger number of settings and associated beds. Specifically, the present study examined the types of facilities that States regulate, regardless of what organizations operate these facilities; it included facilities that provide some therapeutic services beyond room and board, but not necessarily a broad set of clinical psychiatric or psychological services. The SMHO, in contrast, focuses specifically on mental health organizations operated under the auspices of State mental health agencies, and gathers information on the number of these organizations that provide major clinical services in a residential venue. Using yet another approach, the survey of State mental health agencies conducted by the NASMHPD Research Institute asks State agencies to report on the number of beds and the average daily census for residential programs operated and funded by State mental health agencies.

Overall, the present study builds on and extends previous studies of residential set- tings for adults with mental illness. Each of the available studies contributes somewhat different views of residential facilities for adults with mental illness, but the picture remains incomplete. For example, better information is needed on the link between regulatory methods and client outcomes in different types of facilities or organizations. In addition, many States could develop improved reporting methods for residential facilities to ensure that policymakers have reliable information needed for policy and program reforms.

The study's findings also relate directly to the recommendation in the report from the President's New Freedom Commission on Mental Health that each State develop a comprehensive State mental health plan (New Freedom Commission on Mental Health, 2003). As a continuation of the Commission's efforts, SAMHSA, in partnership with key Federal agencies, recently issued the Federal Mental Health Action Agenda (SAMHSA, 2005). One of the five principles outlined in the Action Agenda is to "ensure innovation, flexibility, and accountability at all levels of government." The action steps related to this principle include the initiation of State Mental Health Transformation Grants (first awarded in September 2005) and the provision of technical assistance to help States develop their comprehensive State Mental Health Plans. If these plans include comprehensive and coordinated methods for regulating residential treatment facilities for adults with mental illness, States should be able to minimize redundant and potentially conflicting administrative burdens on such facilities, leverage resources across multiple agencies, and foster a coherent continuum of services for adults with mental illness. 


\section{References}

Fleishman, M. (2004). The problem: How many patients live in residential care facilities? Psychiatric Services, 55, 620622.

Ireys, H., Achman, L., Takyi, A. (2006). State Regulation of Residential Facilities for Children with Mental Illness. DHHS Pub. No. (SMA) 06-4167. Rockville, MD: Center for Mental Health Services, Substance Abuse and Mental Health Services Administration.

Manderscheid, R., J., Atay, A., Male, B., Blacklow, C., Forest, L., Ingram, et al. (2004). Highlights of organized mental health services in 2000 and major national and state trends. In R. Manderscheid \& M. Henderson (Eds.), Mental Health, United States, 2002. DHHS Pub No. (SMA) 3938. Rockville, MD: Substance Abuse and Mental Health Services Administration.

Milazzo-Sayre, L. M., Henderson, R., Manderscheid, M., Bokossa, C., Evans, A., \& Male, B. (2001). Persons treated in specialty mental health care programs, United States, 1997. In R. W. Manderscheid \& M. J. Henderson (Eds.), Mental Health, United States, 2000. DHHS Pub No. (SMA) 01-3537. Washington, DC: Superintendent of Documents, U.S. Government Printing Office.

National Association of State Mental Health Program Directors (NASMHPD). (n.d.). The NASMHPD Research Institute's State Mental Health Agency Profiling System. Retrieved May 2005 from http:// www.nri-inc.org/defprofiles.cfm.
New Freedom Commission on Mental Health. (2003). Achieving the Promise: Transforming Mental Health Care in America. Final Report. DHHS Pub. No. SMA-03-3832. Rockville, MD.

O'Hara, A., \& Day, S. (2001). Olmstead and Supportive Housing: A Vision for the Future. Lawrenceville, NJ: Center for Health Care Strategies.

Randolph, F., Ridgway, P., Sanford, C., Simoneau, \& Carling, P. (1988). A national survey of community residential programs for persons with prolonged mental illness. Boston, MA: Community Residential Rehabilitation Project, Center for Psychiatric Rehabilitation, Boston University and Center for Community Change Through Housing and Support, University of Vermont.

Ridgway, P., \& Zipple, A. (1990). The paradigm shift in residential services: From the linear continuum to supported housing approaches. Psychosocial Rehabilitation Journal, 13(4).

Salzer, M., Blank, M., Rothbard, A. \& Hadley, T. (2001). Adult mental health services in the 21 st century. In R. W. Manderscheid \& M. J. Henderson (Eds.), Mental Health, United States, 2000 (pp. 99-112). DHHS Pub No. (SMA) 01-3537. Washington, DC: Superintendent of Documents, U.S. Government Printing Office.

Substance Abuse and Mental Health Services Administration (SAMHSA). (2005). Transforming Mental Health Care in America. The Federal Action Agenda: First Steps. Washington, DC: United States Department of Health and Human Services. 



\section{Appendix A}

\section{Expert Advisory Panel}

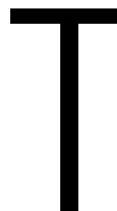

he authors are grateful to the members of the expert advisory panel who provided thoughtful input into study questions, survey methods, and criteria for the residential facilities included in the study; members of this panel are listed below. The authors would like to extend particular thanks to Joy Midman, Sandra Newman, and Tom Harmon for their careful review of an early draft of the survey instrument and for guidance at strategic stages of the study. Jeff Horton of North Carolina, Brenda Harvey of Maine, and Alfred Nichols of California also provided useful feedback during the pilot test of the survey. James Maedke and Nancy Darrow of Social and Scientific Systems, Inc., provided assistance in understanding definitions of mental health organizations used in the Survey of Mental Health Organizations.

At Mathematica Policy Research, Debra Draper played an important leadership role in the first phase of the project. Jesse Gregory and Kathy Bencio spent many hours contacting State officials as part of the survey effort. Myles Maxfield gave us insightful comments on an early draft of the report, and Sharon Clark provided unmatched secretarial assistance in producing the report. The authors extend special thanks to the individuals in the various States who took time to complete the survey and provide the needed information. 


\begin{tabular}{|c|c|c|}
\hline \multicolumn{3}{|c|}{ Expert Advisory Panel List of Participants } \\
\hline \multicolumn{3}{|c|}{ Panel Members } \\
\hline Karen Saltus Armstrong & Collete Croze & Joe Dziobek \\
\hline $\begin{array}{l}\text { Senior Public Health Advisor } \\
\text { Protection \& Advocacy for } \\
\text { Individuals with Mental Illness } \\
\text { (PAIMI) Program } \\
\text { Substance Abuse and Mental Health } \\
\text { Services Administration (SAMHSA) }\end{array}$ & $\begin{array}{l}\text { Consultant } \\
\text { Technical Assistance Collaborative } \\
\text { (TAC) Housing Center }\end{array}$ & $\begin{array}{l}\text { President/CEO } \\
\text { Fellowship Health Resources, Inc. }\end{array}$ \\
\hline Steve Fields & Brian Fitzmaurice & Tom Harmon \\
\hline $\begin{array}{l}\text { Director } \\
\text { Progress Foundation }\end{array}$ & $\begin{array}{l}\text { Director of Community Assistance } \\
\text { Programs } \\
\text { U.S. Department of Housing and } \\
\text { Urban Development (HUD) }\end{array}$ & $\begin{array}{l}\text { Commission Staff } \\
\text { New York Commission on the Quality } \\
\text { of Care for the Mentally III }\end{array}$ \\
\hline Jeff Horton & Bonnie Kirkland & Martha Knisley \\
\hline $\begin{array}{l}\text { Chief of Mental Health Licensure and } \\
\text { Certification } \\
\text { North Carolina Division of Facilities }\end{array}$ & $\begin{array}{l}\text { Special Secretary } \\
\text { Maryland Governor's Office for } \\
\text { Children, Youth, and Families }\end{array}$ & $\begin{array}{l}\text { Director } \\
\text { DC Department of Mental Health }\end{array}$ \\
\hline Joy Midman & Sandra Newman & Fran Randolph \\
\hline $\begin{array}{l}\text { Executive Director } \\
\text { National Association for Children's } \\
\text { Behavioral Health }\end{array}$ & $\begin{array}{l}\text { Director } \\
\text { Institute for Policy Studies } \\
\text { Johns Hopkins University }\end{array}$ & $\begin{array}{l}\text { Acting Branch Chief } \\
\text { Homeless Programs Branch } \\
\text { Substance Abuse and Mental Health } \\
\text { Services Administration (SAMHSA) }\end{array}$ \\
\hline John Rio & Sam Tsemberis & Deborah Wilkerson \\
\hline $\begin{array}{l}\text { Program Director } \\
\text { Corporation for Supportive Housing }\end{array}$ & $\begin{array}{l}\text { Executive Director } \\
\text { Pathways to Housing }\end{array}$ & $\begin{array}{l}\text { Director of Research and Quality } \\
\text { Improvement } \\
\text { Commission on Accreditation of } \\
\text { Rehabilitation Facilities (CARF) }\end{array}$ \\
\hline \multicolumn{3}{|c|}{ SAMHSA Project Staff } \\
\hline Jeffrey Buck & Judith Teich & William Wallace \\
\hline $\begin{array}{l}\text { Associate Director } \\
\text { Office of Organization and Financing }\end{array}$ & Office of Organization and Financing & Office of Organization and Financing \\
\hline \multicolumn{3}{|c|}{ Mathematica Policy Research, Inc. Staff } \\
\hline Debra Draper & Myles Maxfield & Henry Ireys \\
\hline Senior Researcher & Senior Fellow & Senior Researcher \\
\hline Deborah Bukoski & Lori Achman & Ama Takyi \\
\hline Survey Researcher & Research Analyst & Research Assistant \\
\hline
\end{tabular}


Appendix B

Survey Questionnaire 
U.S. DEPARTMENT OF HEALTH AND HUMAN SERVICES
Substance Abuse and Mental Health Services Administration
Www.samhsa.gov

Public reporting burden for this collection of information is estimated to average 1 hour per response, including the time for reviewing instructions, searching existing data sources, gathering and maintaining the data needed, and completing and reviewing the collection of information. Send comments regarding this burden estimate or any other aspect of this collection of information, including suggestions for reducing this burden to SAMHSA Reports Clearance Officer; Paperwork Reduction Project (0930-0251); Room 16105, Parklawn Building; 5600 Fishers Lane, Rockville, MD 20857. An agency may not conduct or sponsor, and a person is not required to respond to, a collection of information unless it displays a currently valid OMB control number. The OMB control number for this project is $0930-0251$.

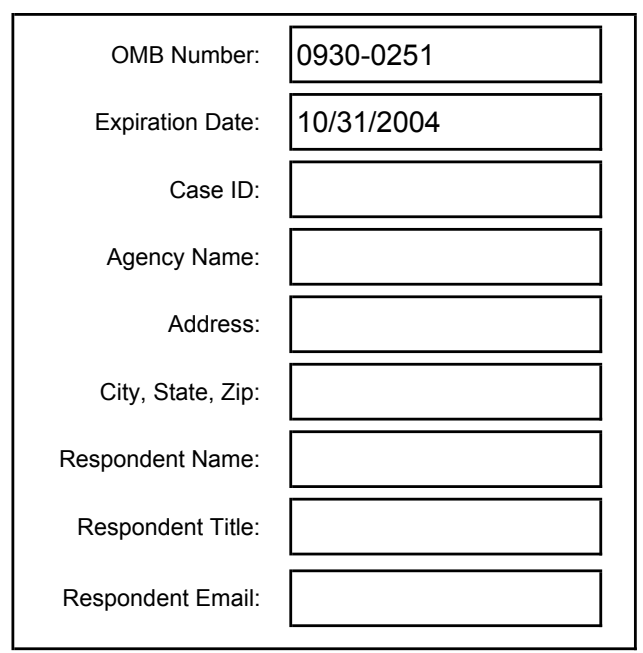

\section{DEPARTMENT OF HEALTH AND HUMAN SERVICES}

SUBSTANCE ABUSE AND MENTAL HEALTH SERVICES ADMINISTRATION

\section{NATIONAL SURVEY OF ADMINISTRATION AND FINANCING OF GROUP HOMES AND RESIDENTIAL FACILITIES FOR PERSONS WITH MENTAL ILLNESS}

\section{FACILITY TYPE HERE}

\section{INTRODUCTION:}

Thank you for agreeing to complete this questionnaire. Your participation is critical to the success of this important project. Instructions for completing and returning the questionnaire are included in a separate document. If you have any questions, please do not hesitate to contact:

Henry Ireys

Senior Researcher, Mathematica Policy Research 600 Maryland Avenue, S.W., Suite 550

Washington, DC 20024-2512

Tel: 202.554 .7536

Fax: 202.863.1763

hireys@mathematica-mpr.com
Lori Achman

Research Analyst, Mathematica Policy Research 600 Maryland Avenue, S.W., Suite 550

or Washington, DC 20024-2512

Tel: 202.264.2464

Fax: 202.863.1763

lachman@mathematica-mpr.com 


\section{Helpful Hints to Complete Your Survey}

While there are many types of facilities in your state, this survey is only asking about [FILL TYPE].

\section{Remember to save often!}

$\Rightarrow$ Use the arrow keys to the left of the Section Tabs at the bottom of the page to navigate left to right to see the sections (tabs).

$\Rightarrow$ Click on the Section Tabs at the bottom of the screen to get to that section. You can skip around between sections and instructions if needed.

$\Rightarrow$ Follow any skips you see after questions. They may be in one of two formats:

(after a choice) $\Rightarrow$ GO TO Q3_a

(at the end of a section) GO TO SECTION C

There are 4 types of questions: Fill-in; Yes/No; Select One; Check All That Apply.

Below are examples of each and how to answer them.

x Yes/No:

\section{Y Yes}

No

In this type of question you will move the mouse (which appears as a hand) over the circle next to the response you'd like, and click. Once you do that, the circle will be filled in. If you'd like to change your answer, simply click on the other choice.

x Fill-In:

\section{ENTER NUMBER OF HOURS PER YEAR:}

In this type of question, you may be entering a number - such as a percent or you may be typing text for an Other (specify) answer.

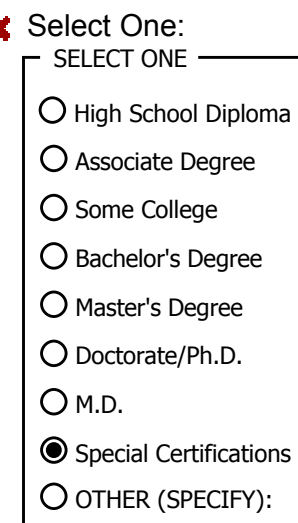

This type of question is similar to Yes/No. Rather than an arrow appearing over the choices, a hand will appear. As with the Yes/No questions, 
you may only choose one (by clicking on the circle beside your choice).

You may change your answer by clicking on a different answer.

* Check All That Apply:

CHECK ALL THAT APPLY

$\square$ Physician

$\square$ Psychologist

$\square$ Nurse

$\square$ social Worker

$\square$ OTHER (SPECIFY

For this type of question, you will also see a hand when you move the mouse over the choices. To select the choices you'd like, click your mouse over the box next to your desired answer. Repeat for all your choices.

To change any answer, click again in the box already filled in. It will become blank again.

\section{Assessing Data Quality}

We recognize that some items may require you to estimate a number. For a limited number of items, we are asking you to indicate whether your answers are based on an estimate or on actual figures in an existing report or database. This will help SAMHSA evaluate the precision and accuracy of the data. Whenever possible, please use actual figures. 


\section{A. FACILITY CHARACTERISTICS}

We would like to start by asking some questions about the characteristics of [FILL TYPE] in your State.

A1. How many of these facilities were licensed in your state as of September 30, 2003?

ENTER NUMBER:

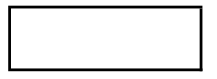

Please indicate whether this figue is an estimate or is the result of record review.

Estimate $\bigcirc$ Record Review

A2. What were the total number of beds in operation in all of these facilities as of September 30, 2003 ?

TOTAL NUMBER OF BEDS:

A2_a. Of these beds, what percent were occupied as of September 30, 2003?

\section{ENTER PERCENT:}

A3. What was the average number of residents in a single facility of this type as of September 30,2003 ?

ENTER AVERAGE NUMBER OF RESIDENTS:

7. Please indicate whether this figue is an estimate or is the result of record review.

Estimate $\bigcirc$ Record Review

A4. Is there a law or regulation in the state that limits the number of beds in a single facility of this type?

Yes $\Rightarrow$ GO TO A4_a

No $\Rightarrow$ GO TO A5

A4_a. What is the maximum number of beds allowed by law or regulation for a single facility of this type?

ENTER NUMBER OF BEDS:

A5. What is the usual age range of residents in these facilities?

ENTER AGE RANGE:

A6. Is there a state law or regulation that specifies the maximum length of stay for residents in these facilities?

$$
\begin{aligned}
& \text { Yes } \Rightarrow \text { GO TO A6_a } \\
& \text { No } \Rightarrow \text { GO TOA7 }
\end{aligned}
$$

A6_a. What is the maximum length of stay for residents of these facilities?

ENTER NUMBER:

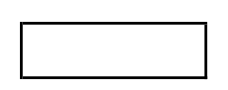

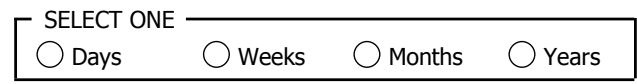


A7. What is the average length of stay for residents of these facilities?

ENTER NUMBER:

$\left[\begin{array}{lll}\text { SELECT ONE } \\ \text { Days }\end{array}\right.$

- Please indicate whether this figue is an estimate or is the result of record review.

A8. Is there a state law or regulation requiring mintmum pattent-to-staff ratios for these facilities?

$$
\text { @ Estimate } \quad \text { : Record Review }
$$

$\because$ Yes $\Rightarrow$ GOTOA8_a

$\because$ No $\Rightarrow$ GO TOA9

A8_a. What are the minimum patient-to-staff ratios during daytime hours?

ENTER NUMBER OF PATIENTS PER STAFF MEMBER:

Not Applicable

A8_b. What are the minimum patient-to-staff ratios during evening hours?

ENTER NUMBER OF PATIENTS PER STAFF MEMBER:

Not Applicable

A8_c. What are the minimum patient-to-staff ratios during overnight hours?

ENTER NUMBER OF PATIENTS PER STAFF MEMBER:

-... Not Applicable

A9. What percentage of these facilities are operated by...

State or Local Governmental Units

Not-for-Profit Organizations

For-Profit/Proprietary Organization

OTHER (SPECIFY):

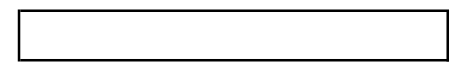

TOTAL

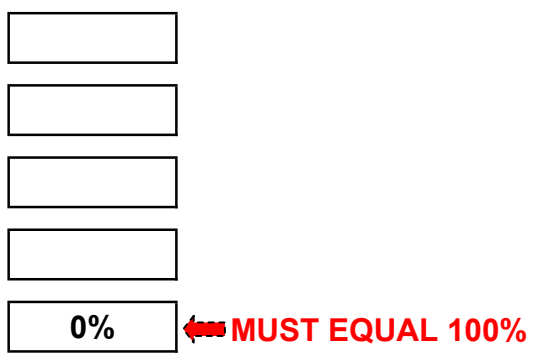

A10. Is there a state law or regulation requiring clinical supervision of direct care workers at these facilities?

NOTE: A direct care worker is defined as an individual who provides active direct care, treatment, rehabilitation or habilitation services to clients.

Yes $\Rightarrow$ GO TO A10_a
No $\Rightarrow$ GO TOA11 
A10_a. What is the minimum number of hours per month that direct care workers must be clinically supervised?

\section{ENTER NUMBER OF HOURS PER MONTH:}

A10_b. What type of individual is allowed to provide this clinical supervision?

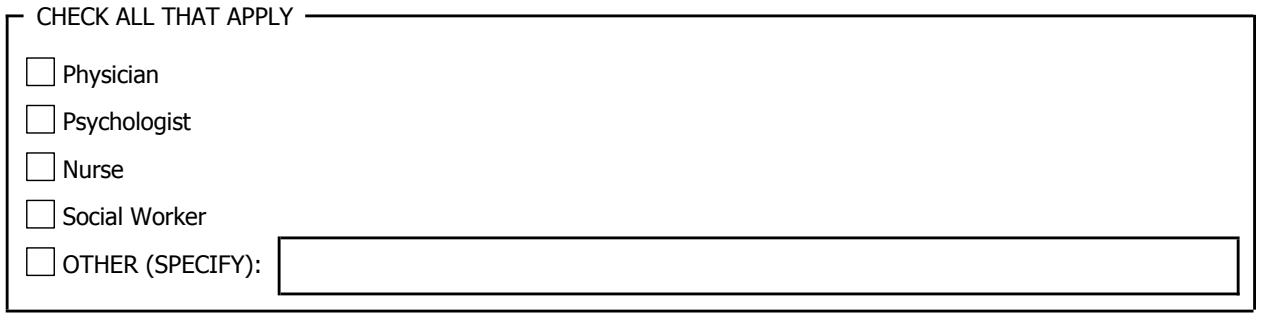

A11. Is there a state law or regulation that requires a minimum amount of education for facility directors?

Yes $\Rightarrow$ GO TO A11_a
No $\Rightarrow$ GO TO A12

A11_a. What is the minimum education required for facility directors?

$\left[\begin{array}{l}\text { SELECT ONE } \\ \text { High School Diploma } \\ \text { Associate Degree } \\ \text { Some College } \\ \text { Bachelor's Degree } \\ \text { Master's Degree } \\ \text { Doctorate/Ph.D. } \\ \text { M.D. } \\ \text { Special Certifications } \\ \text { OTHER (SPECIFY): }\end{array}\right.$

A12. Are facilities required to provide in-service or continuing education for direct care staff?

$$
\begin{aligned}
& \text { Yes } \Rightarrow \text { GO TOA12_a } \\
& \text { No } \Rightarrow \text { GOTOA13 }
\end{aligned}
$$

A12_a. What is the minimum number of hours required per year?

ENTER NUMBER OF HOURS PER YEAR:

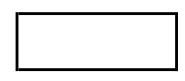


A12_b. Does state law or regulation require that specific topics (e.g., training on confidentiality issues; first aid training) be covered for all or most direct care staff?

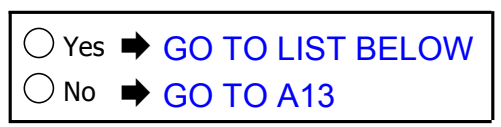

Please List Topics:

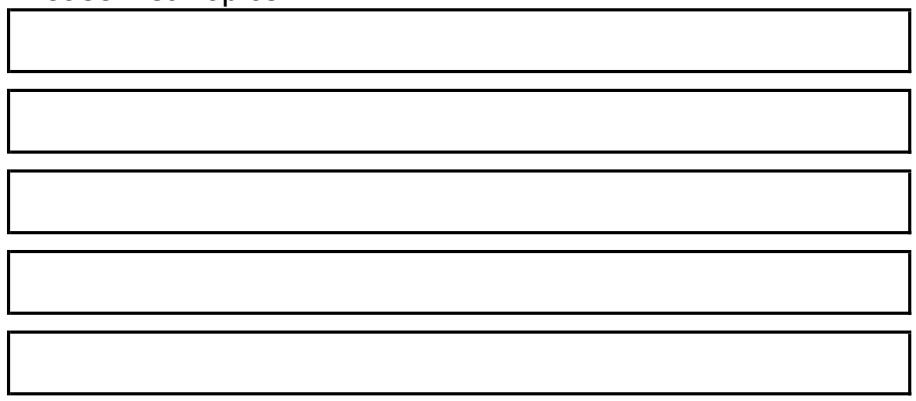

A13. What agency or entity has the authority to hire and terminate facility directors?

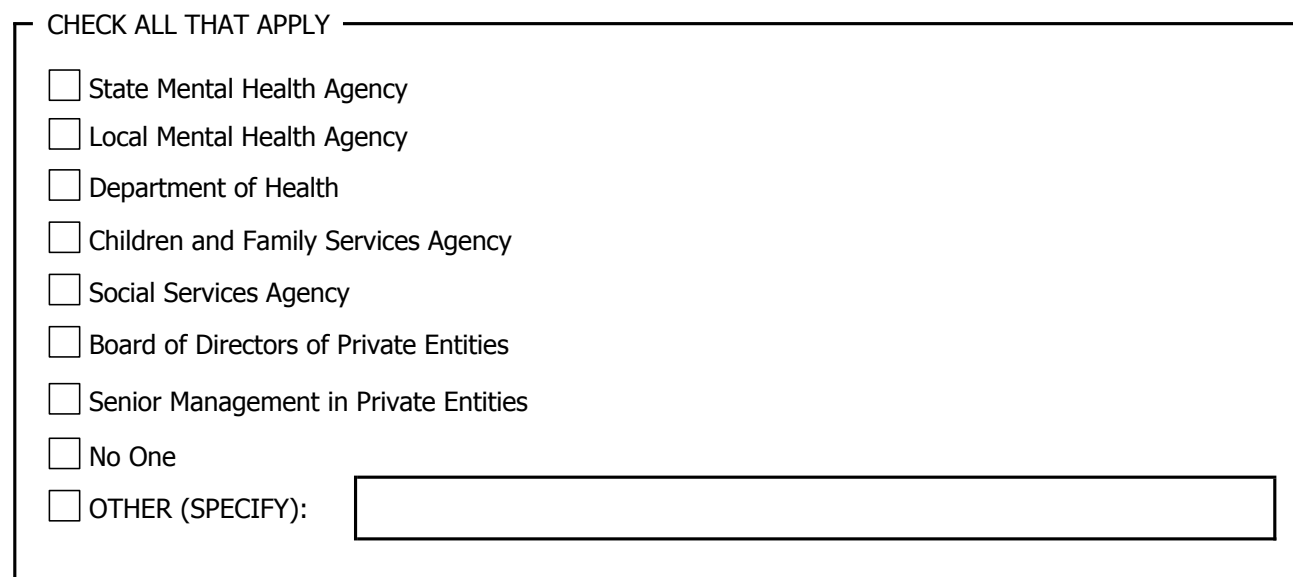

A14. Are these facilities allowed to have locked units?

$$
\begin{aligned}
& \text { Yes } \Rightarrow \text { GO TO A14_a } \\
& \text { No } \Rightarrow \text { GO TO PART B }
\end{aligned}
$$

A14_a. What percent of these facilities have locked units?

$$
\begin{array}{r}
\text { ENTER PERCENT OF FACILITIES } \\
\text { WITH LOCKED UNITS: }
\end{array}
$$

$$
\text { Please indicate whether this figue is an }
$$
estimate or is the result of record review

$$
\text { Estimate } \bigcirc \text { Records Review }
$$

GO TO PART B: LICENSING, CERTIFICATION, \& ACCREDITING 


\section{B. LICENSING, CERTIFICATION, AND ACCREDITATION}

The next questions are about licensure, certification, and accreditation requirements for [FILL TYPE].

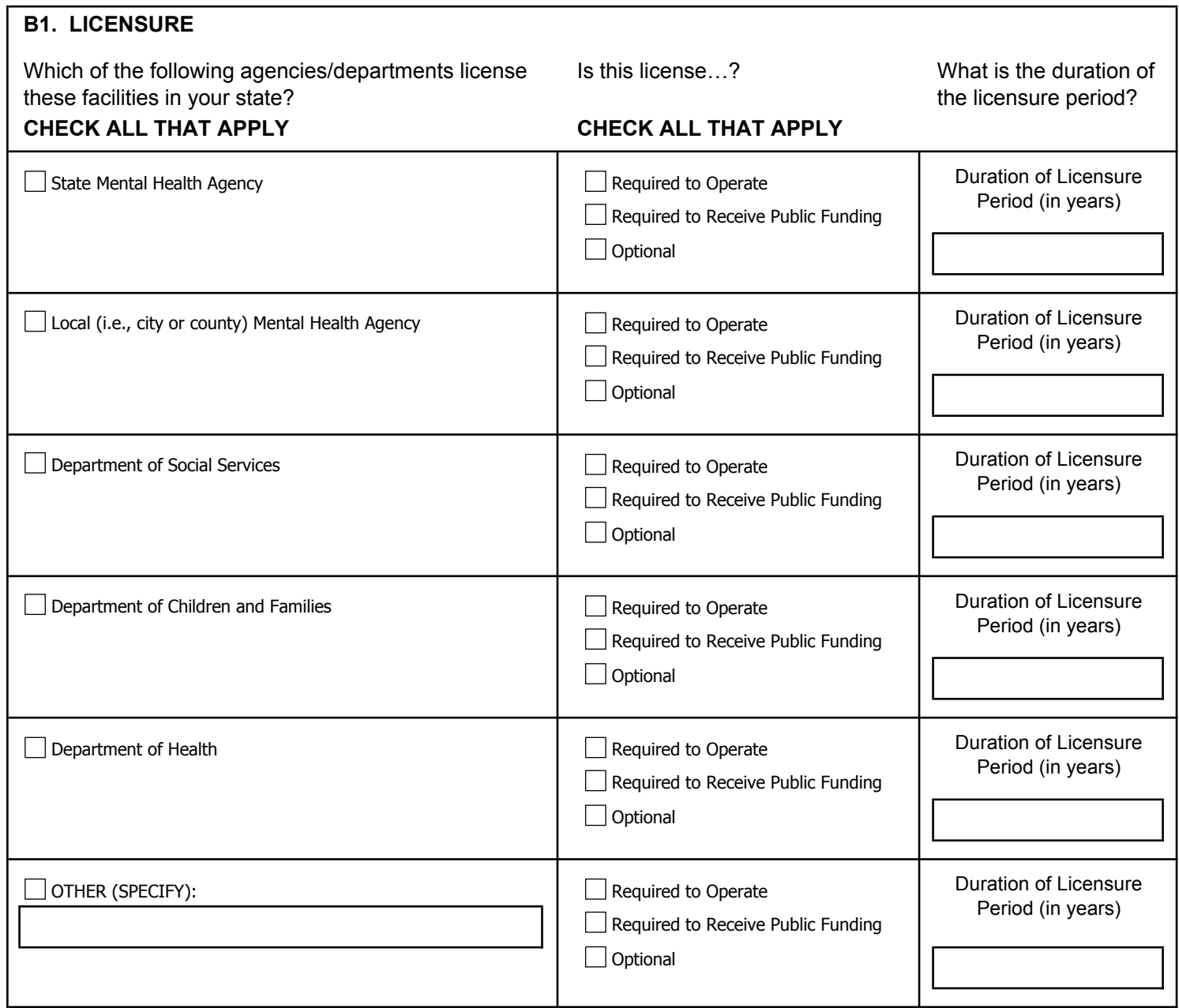




\begin{tabular}{|c|c|c|}
\hline $\begin{array}{l}\text { B2. CERTIFICATION } \\
\text { Which of the following agencies/departments certify } \\
\text { these facilities in your state? } \\
\text { CHECK ALL THAT APPLY }\end{array}$ & $\begin{array}{l}\text { Is this certification...? } \\
\text { CHECK ALL THAT APPLY }\end{array}$ & $\begin{array}{l}\text { What is the duration of } \\
\text { the certification } \\
\text { period? }\end{array}$ \\
\hline$\square$ State Mental Health Agency & $\begin{array}{l}\square \text { Required to Operate } \\
\square \text { Required to Receive Public Funding } \\
\square \text { Optional }\end{array}$ & $\begin{array}{l}\text { Duration of Certification } \\
\text { Period (in years) }\end{array}$ \\
\hline$\square$ Local Mental Health Agency & $\begin{array}{l}\square \text { Required to Operate } \\
\square \text { Required to Receive Public Funding } \\
\square \text { Optional }\end{array}$ & $\begin{array}{l}\text { Duration of Certification } \\
\quad \text { Period (in years) }\end{array}$ \\
\hline$\square$ Department of Social Services & $\begin{array}{l}\square \text { Required to Operate } \\
\square \text { Required to Receive Public Funding } \\
\square \text { Optional }\end{array}$ & $\begin{array}{l}\text { Duration of Certification } \\
\text { Period (in years) }\end{array}$ \\
\hline$\square$ Department of Children and Families & $\begin{array}{l}\square \text { Required to Operate } \\
\square \text { Required to Receive Public Funding } \\
\square \text { Optional }\end{array}$ & $\begin{array}{l}\text { Duration of Certification } \\
\text { Period (in years) }\end{array}$ \\
\hline$\square$ Department of Health & $\begin{array}{l}\square \text { Required to Operate } \\
\square \text { Required to Receive Public Funding } \\
\square \text { Optional }\end{array}$ & $\begin{array}{l}\text { Duration of Certification } \\
\text { Period (in years) }\end{array}$ \\
\hline$\square$ OTHER (SPECIFY): & $\begin{array}{l}\square \text { Required to Operate } \\
\square \text { Required to Receive Public Funding } \\
\square \text { Optional }\end{array}$ & $\begin{array}{l}\text { Duration of Certification } \\
\text { Period (in years) }\end{array}$ \\
\hline
\end{tabular}




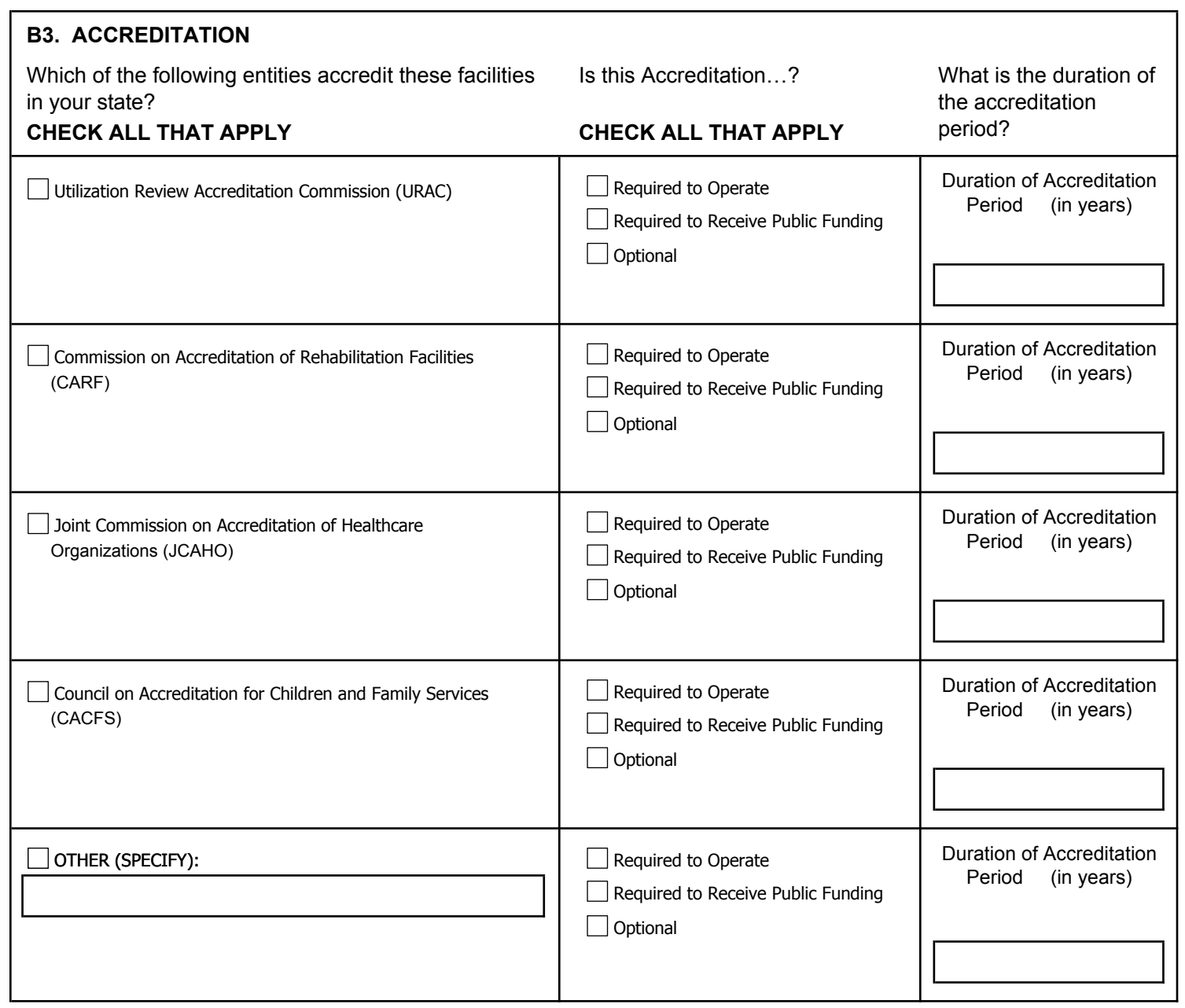


B4. Is there a provisional license process for first-time applicants?

$$
\begin{aligned}
& \bigcirc \text { Yes } \\
& \text { No }
\end{aligned}
$$

B5. What is required for initial licensure, license renewal, certification, and re-certification? CHECK ALL THAT APPLY

\begin{tabular}{|l|c|c|c|c|c|c|}
\hline & $\begin{array}{c}\text { On-Site State } \\
\text { Inspection/ } \\
\text { Visit }\end{array}$ & $\begin{array}{c}\text { Submission of } \\
\text { Documentation of } \\
\text { Staff } \\
\text { Qualifications }\end{array}$ & $\begin{array}{c}\text { Submission of } \\
\text { Documentation } \\
\text { of Staff Training }\end{array}$ & $\begin{array}{c}\text { Record } \\
\text { Review }\end{array}$ & $\begin{array}{c}\text { Resident } \\
\text { Interviews }\end{array}$ & $\square$ \\
\hline Initial Licensure & $\square$ & $\square$ & $\square$ & $\square$ & $\square$ & OTHER (SPECIFY) \\
\hline License Renewal & $\square$ & $\square$ & $\square$ & $\square$ & $\square$ & $\square$ \\
\hline Certification & $\square$ & $\square$ & $\square$ & $\square$ & $\square$ & $\square$ \\
\hline Re-Certification & $\square$ & $\square$ & $\square$ & $\square$ & $\square$ & $\square$ \\
\hline
\end{tabular}

B6. Were any licenses for these facilities in your state revoked or suspended in 2002 ?

Yes $\Rightarrow$ GO TO B6_a, then B6_b
No $\Rightarrow$ GO TO C1

B6_a. How many?

\section{ENTER NUMBER:}

B6_b. What were the reasons?

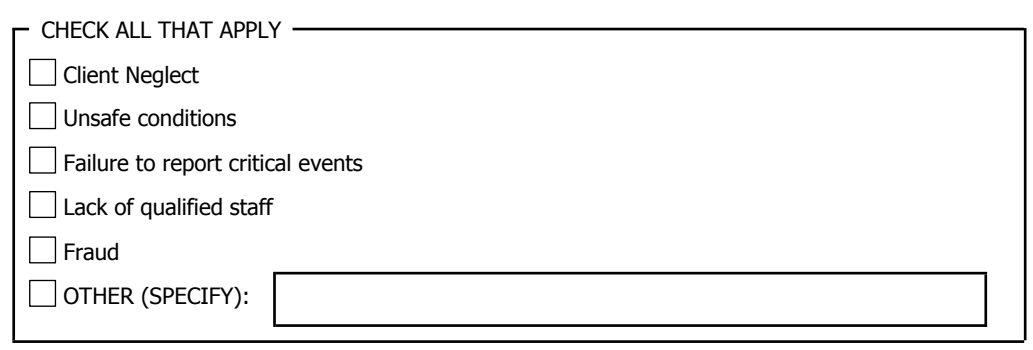

GO TO PART C: FACILITY PROGRAMS \& TREATMENT SERVICES 


\section{FACILITY PROGRAMS AND TREATMENT SERVICES}

In this section we'd like you to answer some questions about the services provided to residents and requirements governing service provision in [FILL TYPE].

C1. Are these facilities required to develop individualized treatment/service plans for residents?

Yes $\Rightarrow$ GO TO C1_a then C1_b
No $\Rightarrow$ GOTOC2

C1_a. How often must the individualized treatment/service plans be updated?
ENTER NUMBER:

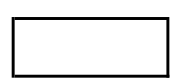
$\left[\begin{array}{lll}\text { PLEASE SPECIFY } \\ \text { Days } \bigcirc \text { weeks } \bigcirc \text { Months } \bigcirc \text { Years }\end{array}\right.$

C1_b. Is the client or parent/guardian required to provide written acknowledgement of the individualized treatment plan?

$$
\begin{aligned}
& \text { Yes } \\
& \text { No }
\end{aligned}
$$

C2. Which of the following services does the state require these facilities to provide, either by staff or through contractual arrangements?

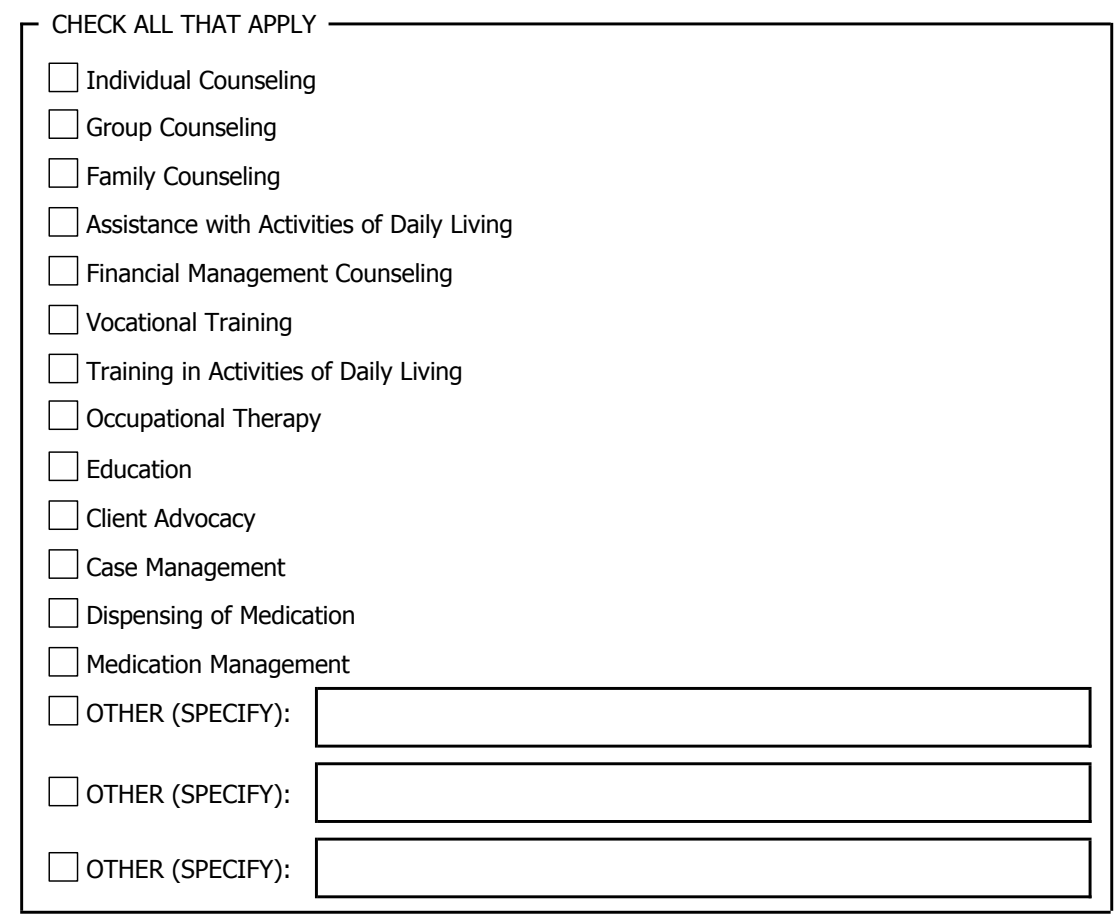


C3. Are these facilities required to provide a minimum number of service/treatment hours to residents? Yes $\Rightarrow$ GOTOC3_a
No $\Rightarrow$ GOTOC4

C3_a. What is the minimim number of service/treatment hours required per resident? ENTER NUMBER: $\square\left[\begin{array}{llll}\text { PLEASE SPECIFY } & \\ \text { D Days } & \bigcirc \text { weeks } & \bigcirc \text { Months } & \bigcirc \text { Years }\end{array}\right.$

C4. Are these facilities required to provide any of the following services upon discharging residents?

$\square$ CHECK ALL THAT APPLY
$\square$ Comprehensive Discharge Plan
$\square$ Followup Visit at Home/Other Residence
$\square$ Followup Treatment or Aftercare Plan Post Discharge
$\square$ Discharge Interview or Satisfaction Survey
$\square$ Discharge Medications or Specific Medication Plan
$\square$ OTHER (SPECIFY):

GO TO PART D: FACILITY MONITORING \& OVERSIGHT 


\section{FACILITY MONITORING AND OVERSIGHT}

The following questions involve procedures for monitoring and overseeing [FILL TYPE].

D1. Did the state make unannounced visits to any of these facilities in 2002 ?

$\bigcirc$ Yes $\Rightarrow$ GO TO D1_a then D1_b and D1_c
No $\Rightarrow$ GO TO D2

D1_a. What percent of these facilities did the state make unannounced visits to in 2002 ? ENTER PERCENT:

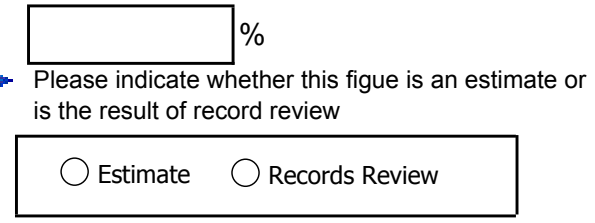

D1_b. What agency or agencies conducted these site visits?
CHECK ALL THAT APPLY
$\square$ State Mental Health Agency
$\square$ Local (i.e., city or county) Mental Health Agency
$\square$ Department of Social Services
$\square$ Department of Children and Families
$\square$ Department of Health
$\square$ OTHER (SPECIFY):
D1_C. What is the minimum required frequency of these visits per facility?
$\square$ No Frequency Rate Required
ENTER NUMBER:

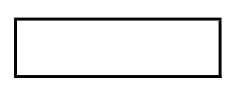

$\left[\begin{array}{ll}\text { PLEASE SPECIFY } \\ \text { Days } \quad \bigcirc \text { weeks } \bigcirc \text { Months } \bigcirc \text { Years }\end{array}\right.$

D2. Did the state make announced visits to any of these facilities in 2002 ?

Yes $\Rightarrow$ GO TO D2_a then D2_b and D2_c
No $\Rightarrow$ GO TO D3

D2_a. What percent of these facilities did the state make announced visits to in 2002 ?

\begin{tabular}{|c|c|c|}
\hline ENTER PERCENT: & & $\%$ \\
\hline & $\begin{array}{l}\text { Please indicate } \\
\text { is the result of re }\end{array}$ & $\begin{array}{l}\text { hether this figue is an } \\
\text { ord review }\end{array}$ \\
\hline & Estimate & Records Review \\
\hline
\end{tabular}


D2_b. What agency or agencies conducted these site visits?

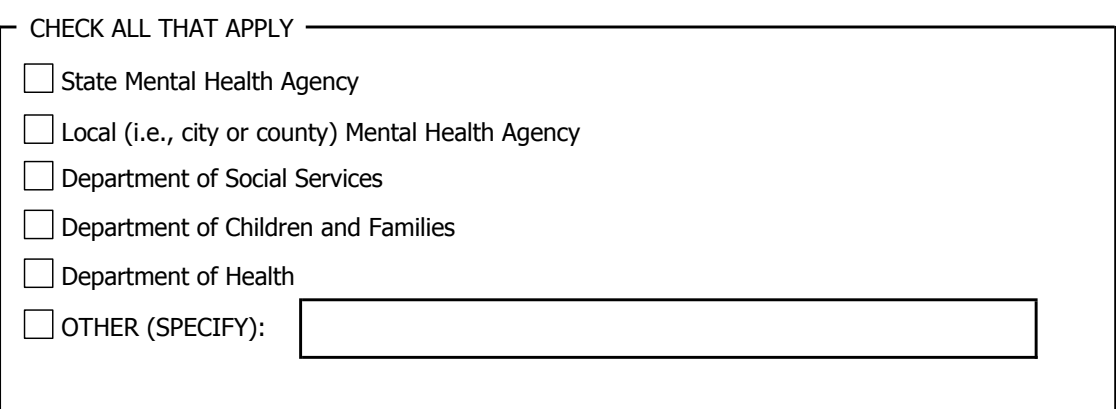

D2_c. What is the minimum required frequency of these visits per facility?

$\square$ No Frequency Rate Required

ENTER NUMBER:

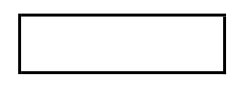

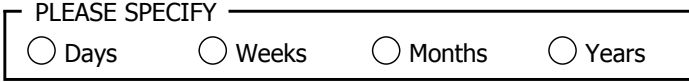

D3. What agency (or agencies) reviews complaints and/or grievances about these facilities?

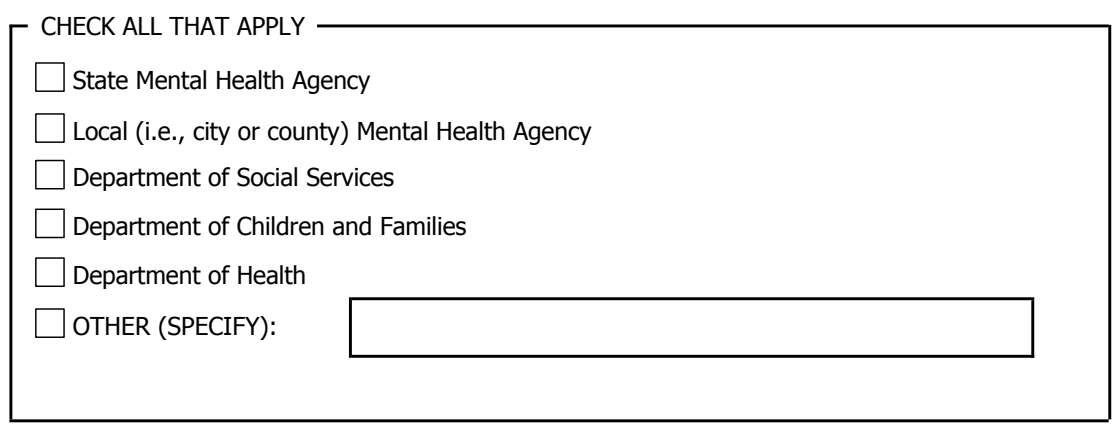

D4. Are these facilities required to report adverse events or incidents to the state?

Yes $\Rightarrow$ GO TO D4_a
No $\Rightarrow$ GO TO D5

D4_a. What types of adverse events or incidents must be reported?

$\square$ CHECK ALL THAT APPLY
$\square$ Deaths
$\square$ Suicides
$\square$ Suicide Attempts
$\square$ Hospitalization of a Resident
$\square$ Allegations of Abuse or Neglect
$\square$ Other Critical Incidents:


D5. Is there a court order in effect that is influencing any monitoring or oversight procedures for these facilities?

Yes $\Rightarrow$ GO TO D5_a

No $\Rightarrow$ GO TO PART E

D5_a. Please describe the nature of any court orders in place.

GO TO PART E: FINANCING 


\section{E. FINANCING}

These questions involve financing of services in [FILL TYPE].

E1. For a typical facility, where does financial support come from? Check all the apply.

Medicaid

State/Local Mental Health Agency Funds

State/Local Family/Child Service Agency Funds

State Welfare Agency

SSI Payments

SSDI Payments

State Supplemental Payments (SSP)

Federal Grants

Department of Education

Juvenile Justice

Department of Defense

Private Grants

Private 3rd Party Payments

Self Pay

OTHER (SPECIFY):

OTHER (SPECIFY):

OTHER (SPECIFY): 
E2. For these facilities, are there different per diem rates for treatment services applied to different groups of Medicaid patients (for example, a group of residents with more severe problems might be charged a higher rate)?

Yes $\Rightarrow$ GOTOE2_a
No $\Rightarrow$ GOTOE3

E2_a. What is the range?

ENTER THE RANGE:

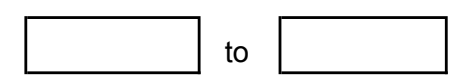

E3. For a typical facility of this type, what is the Medicaid per diem for treatment services?

ENTER AVERAGE DAILY RATE:

Please indicate whether this figue is an estimate or is the result of record review.

$\bigcirc$ Estimate $\bigcirc$ Record Review

\section{THANK YOU FOR TAKING THE TIME TO COMPLETE THIS SURVEY.}

PLEASE EMAIL IT TO [RESEARCHER] AT [EMAIL] .

OR

MAIL IT TO [RESEARCHER] AT 600 MARYLAND AVE., SW STE. 550, WASHINGTON, DC 20024 




DHHS Publication Number (SMA) 06-4166

Printed 2006

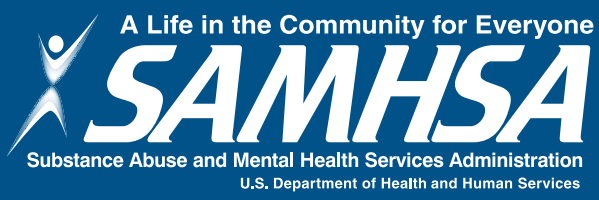

